\title{
Composition of the Microorganism Community Found in the Soil Cover on the Dried Seabed of the Aral Sea
}

\author{
Galina Stulina1, Nadejda Verkhovtseva², Maria Gorbacheva ${ }^{2}$ \\ ${ }^{1}$ International Fund for the Aral Sea Saving, Interstate Coordination Water Commission, Scientific-Information Center (SIC \\ ICWC), Tashkent, Uzbekistan \\ ${ }^{2}$ Lomonosov Moscow State University (MGU), Moscow, Russia \\ Email: galina_stulina@mail.ru
}

How to cite this paper: Stulina, G., Verkhovtseva, N., \& Gorbacheva, M. (2019). Composition of the Microorganism Community Found in the Soil Cover on the Dried Seabed of the Aral Sea. Journal of Geoscience and Environment Protection, 7, 1-23.

https://doi.org/10.4236/gep.2019.78001

Received: May 6, 2019

Accepted: August 9, 2019

Published: August 12, 2019

Copyright $\odot 2019$ by author(s) and Scientific Research Publishing Inc. This work is licensed under the Creative Commons Attribution International License (CC BY 4.0).

http://creativecommons.org/licenses/by/4.0/

\begin{abstract}
As a result of the Aral Sea shrinkage, the unique freshwater body has given place to a huge bitter-saline lake with an area 3.5 times less, volume 6 times less and water salinity 10 times larger than in 1960, and the saline desert at the interface between three sand deserts with an area of more than 5 million ha, being unstable ecological zone. The exposed ground is illustrative of arid salt-accumulation, where was created specific type of soil-costal solonchak. The origination of life in the soil of the dried bed starts long before the occurrence of external characteristics. This process can be traced only by studying the microbiological composition of soil. Research in this direction, was conducted in order to determine the microbiological composition of soil for horizons of one typical profile of solonchak. The research objective was to determine microorganism species in the soil on the dried seabed, identify changes in the microorganism community along the soil profile and dependence on duration of the drying process. Additionally, we paid attention to a vegetation effect on the composition of microorganisms. Soil samples were taken along a transect from the sea to the mainland, selected from the different depth of soil profiles taken under or near plant (saxaul). The method Gas chromatography mass-spectrometry was used. Bacteria of the community of microorganisms in different parts of the soil cover on the dried seabed of the Aral Sea and on the mainland belong to five bacterial phyla: Proteobacteria Actinobacteria Firmicutes Bacteroidetes and Deinococcus-Thermus. In general, 59 bacterial species of 43 genera were reconstructed. The total population varied from $10^{5}$ cells/g to $10^{8}$ cells/g of the soil. The association Aeromonas hydrophila-Arthrobacter sp. played the key role at the first stages of the soil formation process on the dried seabed of the Aral Sea. This association is followed by salt-resistant Agrobacterium sp. and humus-accumulating Pro-
\end{abstract}


pionibacterium freudenreichii, activity of which is also very important for the formation of the soil cover. The studying properties of the dried seabed cover of both salt composition and microbiological composition made it possible to trace the formation of primary soil on marine sediments with the subsequent formation of desert-type soil.

\section{Keywords}

Aral Sea, Dried Seabed, Soil Formation, Microorganism Community, Diversity of Microorganisms

\section{Introduction}

Drying up of the Aral Sea and occurrence of a vast desert in its place has been recognized as the world's century catastrophe!

More than $2 \mathrm{~km}$ of the seabed become exposed every year. Now, the distance from the sea to the former seaport Muynak is $150-200 \mathrm{~km}$ that is covered by a salt desert. This desert is referred to as Aral Kum (the Aral sands) and develops its very own specific fauna, flora, natural landscapes and characteristics. Desertification processes which usually occur over centuries have been accelerated by anthropogenic influence now and reveal their devastating effects within the life cycle of one generation (Dukhovny et al., 2008). Soil, hydrogeological, hydrological, and botanic conditions were studied in the course of the comprehensive ground-based monitoring by SIC ICWC. The soil studies indicated to formation of desert soil instead of solonchak soil under 10-year-old saxaul bushes (Stulina \& Sektimenko, 2004; Dukhovny et al., 2008). The soil formation processes on the dried seabed need to be studied in details.

Microbiological processes are considered as one of soil formation factors.

The speed of processes passing in Aral makes us capture the current state; otherwise we could miss an opportunity of studying such unique process of the formation of desert soil in place of the dried parent material.

The origination of life in the soil of the dried bed starts long before the occurrence of external characteristics. This process can be traced only by studying the microbiological composition of soil. This way, it is possible to answer a question when, after drying up of the sea, the bottom sediments are transformed into the soil and when one can consider the bottom cover as the soil?

Project "Comprehensive remote sensing and ground based studies of the dried Aral Sea bed" with financial support by GTZ (German Technical Cooperation) Agency. Based on the results of these studies, a book (Dukhovny et al., 2008) was published in 2006. The monitoring of the dried seabed was continued in 2006-2011.

Recent expeditions were held jointly with the Germany Center of Earth Studies, Potsdam within the framework of the CAWA Project "Central Asian Water". The expeditions were comprehensive, i.e. the group of researchers included 
environmentalists, soil scientists, hydrologists, and GIS experts.

As special a question of the investigation, the microbiological research was included in program.

\section{Research Subject and Methods}

The subject of the research was the soil cover of the dried bed of the Aral Sea.

The exposed area in the Uzbek territory is more than 2 million ha (Figure 1).

In the course of expeditions (2005-2011) the soil studies included:

1) Field surveys of soil cover

2) Laboratory analyses of soil samples

3) Analysis of collected data and production of soil maps.

Field surveys implied description of the terrain to be studied, selection of key sites, cutting of soil profiles, morphological description of the profiles by genetic horizon, and sampling. The soil was described standardly. Soil samples were brought to laboratory for determination of chemical and physical properties of the soil, salt content from water extract, anion and cation composition, organic matter, gypsum and carbonate in the soil, and soil texture (Dukhovny et al., 2008).

The microbiologic research was conducted in 2010 and 2015. The research objective was to determine microorganism species in the soil on the dried seabed, identify changes in the microorganism community along the soil profile and dependence on duration of the drying process. Additionally, we paid attention to a vegetation effect on the composition of microorganisms. In this context, in 2010, soil samples (14 samples) were taken along a transect from the sea to the mainland (profiles 810-817).

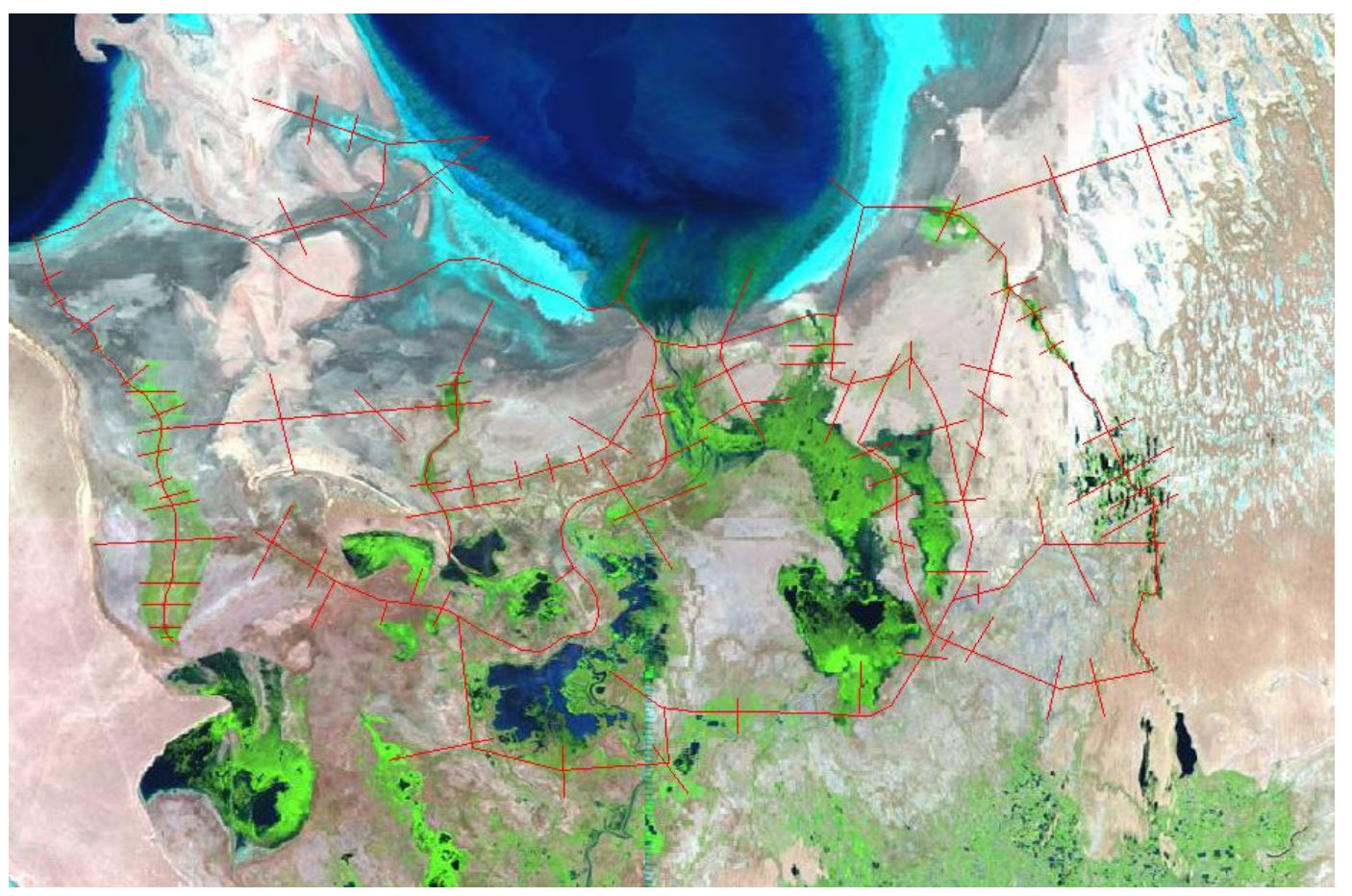

Figure 1. Scheme of field studies on the dried bed of the Aral Sea. 
In 2015, soil samples (67 in total) were taken from 22 profiles (901-922) selected from the layers at the depth of $0-10,10-30$ and $30-50 \mathrm{~cm} .27$ samples were taken under or near saxaul (profiles 902, 904, 906, 909, 913, 914, 917, 918, and 922). Samples were taken from the depth of $50-65 \mathrm{~cm}$ for two profiles $(921$ and 922).

\section{Methods of Microbiological Studies}

Two approaches were used in the studies of microorganism communities on the Aral Sea dried seabed.

The initial task was to determine population of microorganisms in different physiological groups by plating on selective medium.

Then quantitative and qualitative assessment of microorganisms was made by a molecular method against fatty acids (FA), aldehydes and hydroxy fatty acids and microorganisms were reconstructed against these markers to genus and even type in some cases. Such detailed determination of microbial community composition of different phonological groups allows identifying the role of microorganisms in soil formation process.

The analysis consists in direct extraction, using a chemical procedure, of higher fatty acids, aldehydes and sterines from the soil sample under consideration, their separation by gas-liquid chromatography in high-resolution capillary column and analysis of composition in dynamic mode by using mass-spectrometer. Chromatograph is integrated with mass-spectrometer into a single tool and provided with a computer and relevant software for automatic analysis and processing of data. As a result, concentration of microbial markers is determined and composition and structure of the microbial community are reconstructed.

Determination of microorganisms through up-to-date methods is the unique work.

The results and further similar research will allow identifying trends of further changes in composition.

In 2010, the traditional plating method of inoculation of medium was used in given work.

As a result of plating, bacterial genera were identified and approximate percentage in each medium was estimated.

To determine the population of ammonifiers, oligonitrophiles, nitrogen fixers, phosphorus-mobilizing microorganisms, micromycetes and actinomycetes, the research was carried out in three steps on the solid agarized selective medium:

preparation of a series of soil suspensions;

plating on agarized selective medium;

determination of the population of grown colonies.

The following selective growing media (Zvyagintsev, 1991) were used in the analysis: fish-extract agar medium for ammonifiers; Ashby medium (Sigma-Aldrich, A1715, A1840) for oligonitrophiles and nitrogen fixers; Pikovskaya's medium (Sigma-Aldrich, P1602) for phosphorus-mobilizing microorganisms; 
Czapek medium (Sigma-Aldrich, C6220) for micromycetes and actinomycetes;

Hetchinson and Kleiton medium for cellulose-fermenting aerobic microorganisms; Omelyanskiy medium for cellulose-fermenting anaerobic microorganisms; Giltai medium for denitrifiers;

Soriano and Woker medium for $1^{\text {st }}$ phase nitrifiers; Watson and Woterberi medium for 2 nd phase nitrifiers;

Vinogradskiy medium for anaerobic nitrogen-fixing bacteria.

One of the most advanced methods for identifying, studying and quantifying microorganisms in their natural habitat is the luminescence microscopy in incident light.

As the main method for preliminary processing of samples for the microbiological analysis, an ultrasonic dispersion using low-frequency disperser UZDN-1 was applied ( $22 \mathrm{kHz}, 0.44 \mathrm{~A}, 2 \mathrm{~min})$.

The total quantity of microorganisms was estimated through the luminescence microscopy.

Chemodiagnostics using gas chromatography-mass-pectrometry was used to study the biodiversity of soil microorganisms in 2015. The composition of microbial community was determined through GC-MS using the Agilent Technologies HP-5973 system (USA). This method reconstructs the composition of microorganism community by analyzing chemical components of fatty-acid profile of the bacteria's membrane structure, the so called markers (cholesterol was used as a marker for microfungi), and then finding a match in the available data bank (Osipov, 1997; Osipov \& Turova, 1997; Verhovtseva \& Osipov, 2008).

Methodology. The lipid components were extracted from soil samples by acidic methanolysis from milled and averaged air-dry basis, $200 \mathrm{mg}$, in $600 \mu \mathrm{l} 1$ $\mathrm{M} \mathrm{HCl}$ in methanol during one hour at $80^{\circ} \mathrm{C}$. At the sage of methanolysis, fatty acids and aldehydes release from complex lipids of cell membranes. As a result, we had fatty acids in form of methyl ether and aldehydes in form of dimethyl acetals. They were extracted from the reaction mixture in $400 \mu \mathrm{l}$ hexane with addition of spike-trideutero-methyl ether of tridecanoic acid. Small yield of fatty acids - 10 times lower as usual-was found when analyzing some of samples from the dried bed of the Aral Sea. The minerals releasing gas when reacting with acid were found in the soil. It seems that the acid was consumed during the reaction, whereas $\mathrm{HCl}$ was not enough for the release of fatty acids and achievement of appropriate $\mathrm{pH}$ for their further extraction by hexane. Therefore, if gas is released in contact with acid, we waited when the reaction stops and added 20 $\mu \mathrm{l}$ of concentrated $\mathrm{HCl}$. When the gas release stopped, the sample was put into a thermostat. If gas continued releasing in process of heating, we added a drop of concentrated HCI (with hexane and spike) before extraction.

The extract was dried out and treated by $25 \mathrm{mcl} \mathrm{N}, \mathrm{O}-$ bi(trimethylsilyl)- trifluoroacetamide during $15 \mathrm{~min}$ at $80^{\circ} \mathrm{C}$ to get trimethylsilyl ethers of oxyacids, spirits and sterols. $1.6 \mu \mathrm{l}$ of resulting solutions were injected into chromatography mass-spectrometer. 
Chromatography mass-spectrometry analysis. The research was carried out using GC-MS HP-5973 SMART of Agilent Technologies (USA). The quadrupole mass-spectrometer with the mass range of 2 - $1000 \mathrm{Da}$ has the resolution of 0.5 Da. $\mathrm{EI}$ is $70 \mathrm{eV}$. Sensitivity is $1 \mathrm{pg}$ methyl stearate in continuous scanning and $10 \mathrm{pg}$ in selected ion monitoring. An open tubular column made of fused quartz-20 m long, $0.25 \mathrm{~mm}$ in inner diameter, and $0.2 \mu \mathrm{m}$ layer of stationary phase-was used for chromatographic separation of samples. The chromatographic procedure was conducted within the temperature range of $135^{\circ} \mathrm{C}$ to $320^{\circ} \mathrm{C}$ at a rate of 7 degree/min. The temperature of injector is $280^{\circ} \mathrm{C}$ and that of interface is $250^{\circ} \mathrm{C}$.

Mass fragmentography. The mass fragmentography method was used for search of minor biogenic elements. We used the multi-ion detection program, which accumulates signals of 85 specific ions of fatty acids, aldehydes and sterols-markers of microorganisms. Mass-spectrometer was operated in periodic scanning mode of 15 to 20 ions in 5 time intervals. The intervals and ions were chosen in such a way so that to make selected detection of markers of the microorganisms to be identified. Also, strong ion $\mathrm{m} / \mathrm{z}=87$ of fatty acids was used for detection of small microbial acids C12 - C15, C17, and C19, while ion 75 was used for detection of dimethyl acetals. Ion 175 was used in every mode for detection of $\beta$-hydroxy acids, for which the former is specific and intensive in given range. Ions 301, 315 and further in 14 mass units are the indicators (M-15) of the molecular ion of oxyacids-tridecanoic, tetradecanoic and further ones in the homologous series. Ion 312, as a molecular one, is taken to identify isomers of nonadecanoic acid. Such algorithm of detection of mass-spectral parameters of a biological sample determines about 200 of known fatty acids, aldehydes and sterols in microorganisms. Those are enough for detection and quantitative assessment of more than 170 microorganism taxons on a scale of genus or species.

Peaks of markers on mass fragmentograms were integrated automatically and controlled manually by embedded programs. Then, the data was inputted into a calculation EXCEL-based routine. Validation of substances through mass spectrums was made using standard repository NIST in the mass-spectrometer's software.

\section{Results and Discussion}

Based on the results of work in 2010, the following conclusions may be made from this work:

1) Actinomycetes are not developed in given soil layers and horizons.

2) Maximum quantity and biomass of bacteria was observed in layer 1 (0 - 1 $\mathrm{cm})$, layer $4(37-44 \mathrm{~cm})$ and layer $5(44-61 \mathrm{~cm})$.

3) Maximum quantity and biomass of fungus mycelium is observed in the two upper layers: 1-(0 - 1); 2-(1-12 cm).

4) Fungi mycelium is developed only in the two upper layers.

5) Population of fungi spores is the same in all the soil layers and amounts to $2 \times 10^{6}$ cells $/ g$ of the soil. 
These results can be considered as unique. They characterize the soil bacterial community of the dried bed of the Aral Sea. In order to improve methodology, one may apply molecular-genetic research methods in order to identify and refine DNA of certain genus of bacteria, make sequencing, and by getting a sequence of nucleotides with probability of $99 \%$, we can evaluate accuracy of the plating method.

New methods can be developed through given research in order to assess diversity of microorganisms in the soil, which contribute to occurrence of life on the dried bed of the Aral Sea. Perhaps, it is advisable to assess bacterial diversity per each soil horizon. And it is important to choose media more thoroughly for identifying bacterial genuses.

The received results show that solonchak of the dried seabed is mainly comprised of the following microorganisms: 56\% of Pseudomonas, which is responsible for mineralization of easily accessible organic compounds; and, $24 \%$ of $\mathrm{Ba}$ cillus, which keeps further process of deeper mineralization of organic matters.

Final stages of mineralization are maintained by oligotrophic plants that can exist on poor organic medium.

We have studied quantity of major taxonomic and ecological-trophic groups of soil microorganisms on the Aral Sea bed that take part in the cycle of nitrogen, phosphorus and other macro- and microelements-ammonifiers; nitrifiers of $1^{\text {st }}$ and $2^{\text {nd }}$ phase; nitrogen fixers; denitrifiers; oligo-neutrophils; phosphorus mobilizing, cellulose-fermenting aerobes and anaerobes; micromycetes (microscopic fungi) and actinomycetes. Soil sections were cut along the line from the sea to mainland.

Figure shows the composition of microorganisms in the upper soil layer located in the place of 20-year drying process.

In the soil sample of the profile $810(0-5 \mathrm{~cm})$ no beneficial groups of soil microorganisms were found, except for cellulose-fermenting aerobes $\left(10^{8} \mathrm{CFU} / \mathrm{g}\right.$ of soil), anaerobes $\left(10^{6} \mathrm{CFU} / \mathrm{g}\right.$ of soil), and actinomycetes $\left(10^{3} \mathrm{CFU} / \mathrm{g}\right.$ of soil) (Figure 2$)$.

Denitrifiers were found in the sample of soil profile $815(0-20 \mathrm{~cm})$ cut on the dried seabed near the original coast. This indicates to losses of nitrogen from the

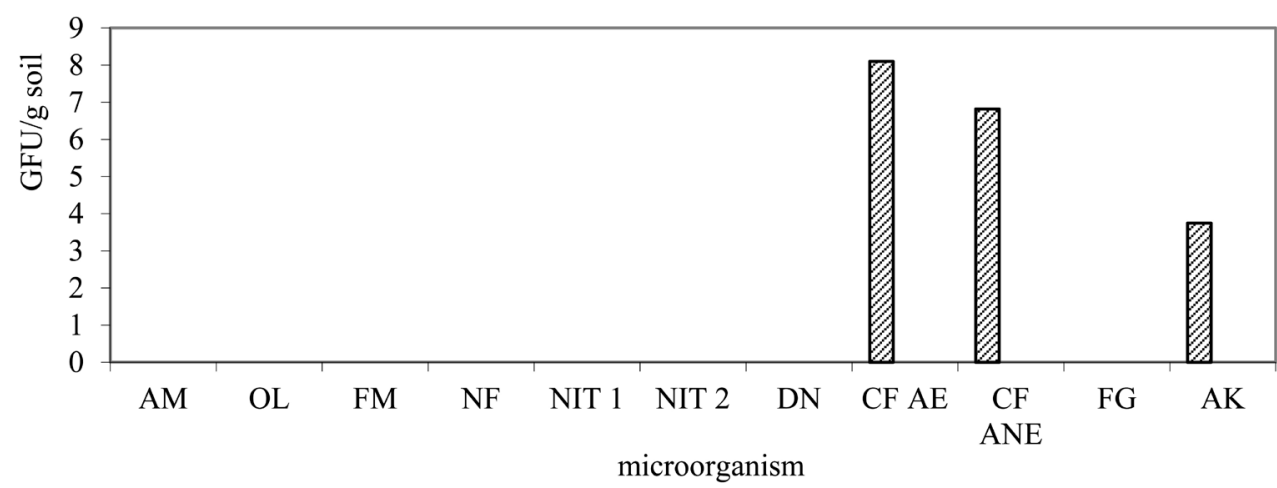

(AM-ammonifiers, OL-oligo-nitrophils, FM-phosphorus mobilizing, NT-nitrifiers, DN-denitrifiers, CF AE-cellulose-fermenting aerobes, CF ANE—cellulose-fermenting anaerobes, FG_Fungi, AK-actinomycetes).

Figure 2. Population of microbal community in soil samples No. 810. 
soil. Presence of fungi and actinomycetes is illustrative of destruction processes regarding complex polymer compounds in the soil.

Decomposition of nitrogen-bearing organic matters took place (Figure 3 ) in all samples from profile No. 815. This is evidenced by presence of ammonifiers and cellulose-fermenting microorganisms.

One can conclude from the obtained results that the decomposition processes driven by cellulose-fermenting bacteria take place in all samples, irrespective of sampling location. Presence of ammonifiers in the samples implies nitrogen and phosphorus cycling, i.e. the initial process of fertility formation.

The results of reconstructed composition of microorganisms in the samples studied in 2011 by chromatography mass-spectrometry analysis are demonstrated in Tables 1-5.

Quantification of total bacteria population of four bacterial phyla indicated to wide variations of this indicator for both bare soils and the soil under saxaul (Figure 4 \& Figure 5).

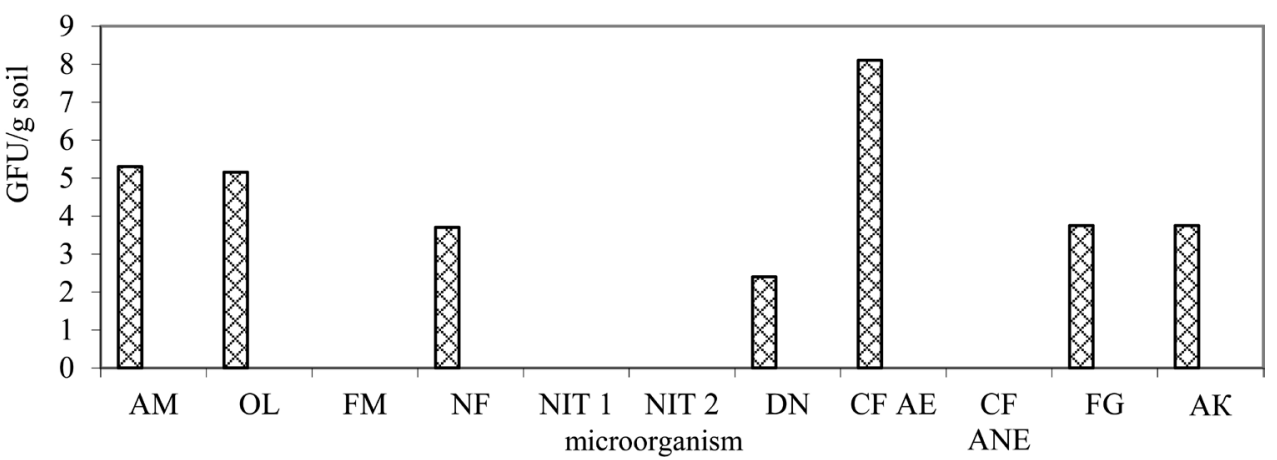

(AM-ammonifiers, OL-oligo-nitrophils, FM-phosphorus mobilizing, NT-nitrifiers, DN—denitrifiers, CF AE-cellulose-fermenting aerobes, CF ANE-cellulose-fermenting anaerobes, FG-Fungi, AK-actinomycetes).

Figure 3. Population of microbial community in soil samples of profile 815.

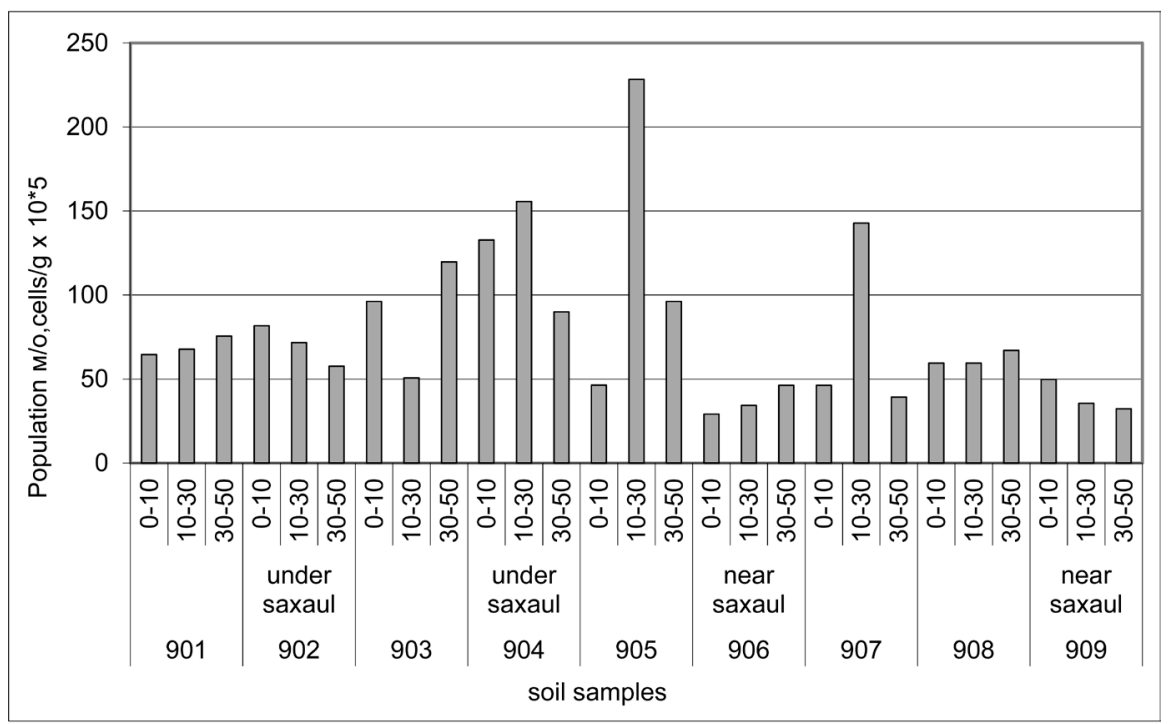

Figure 4. Total population of microorganisms in different soil covers on the exposed bed of the Aral Sea (profiles 901-909). 


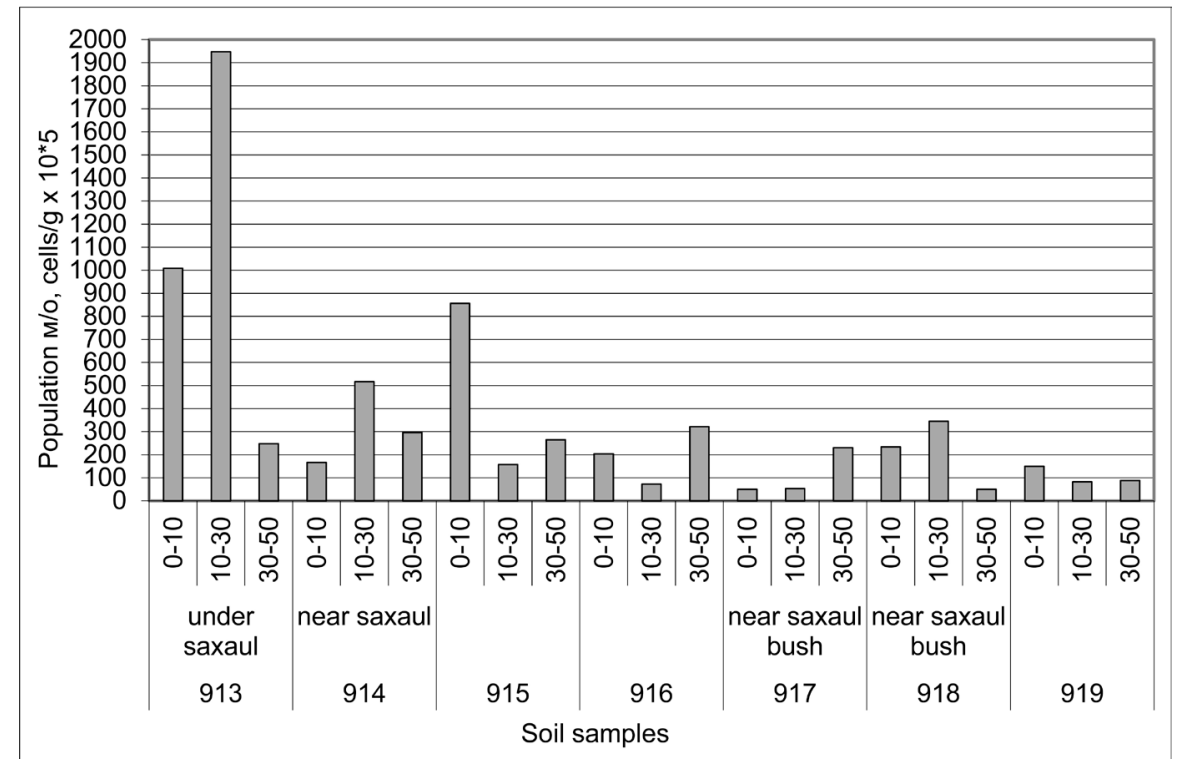

Figure 5. Total population of microorganisms in different soil covers on the exposed bed of the Aral Sea (profiles 913-919).

The population varied from $10^{5}$ cells/g (profiles 901 and 902) to $10^{8}$ cells/g of the soil (profile 913). This seems to be related to the irregular formation pattern of the soil and the diversity of soil cover on the dried seabed of the Aral Sea. Moreover, as is commonly known, in arid areas, plants have a dual effect on salt content in the upper soil horizons-they both increase and reduce salinity of soil. If the leaf litter is highly saline, as it is the case for saxaul, then the soil salinity increases (Rabotnov, 1992). It is saxaul, which initially occupied the dried seabed of the Aral Sea and shaped the local soil cover formation patterns. A comparison of the total population of microorganisms in soil samples taken on the mainland, near saxaul and on bare land has demonstrated that the mainland is richer in terms of microorganisms at all studied depths. The population of microorganisms is threefold on the mainland as compared to the soil near saxaul and seven times higher than in the soil cover on bare land of the dried seabed (Figure 6).

However, there were also profiles under saxaul (profile 913) and bare land areas (profile 915), where the total population of microorganisms was comparable with that on the mainland (Figure 5). Thus, the total population of microorganisms was not indicative for the soil on the dried seabed of the Aral Sea in different environmental contexts. Additional evidence was provided by the analysis of the composition of microbial community as reconstructed by mass-spectrometric microbial markers (Tables 1-5).

In general, 59 bacterial species of 43 genera were reconstructed. However, only some species have population of more than $10^{5} \mathrm{cells} / \mathrm{g}$ of the soil.

For analysis of the soil formation process on the dried seabed of the Aral Sea, let's compare contents of soil species in the same samples of profiles 918 (under saxaul), 919 (bare land) and 920 (mainland), see Figure 7. 


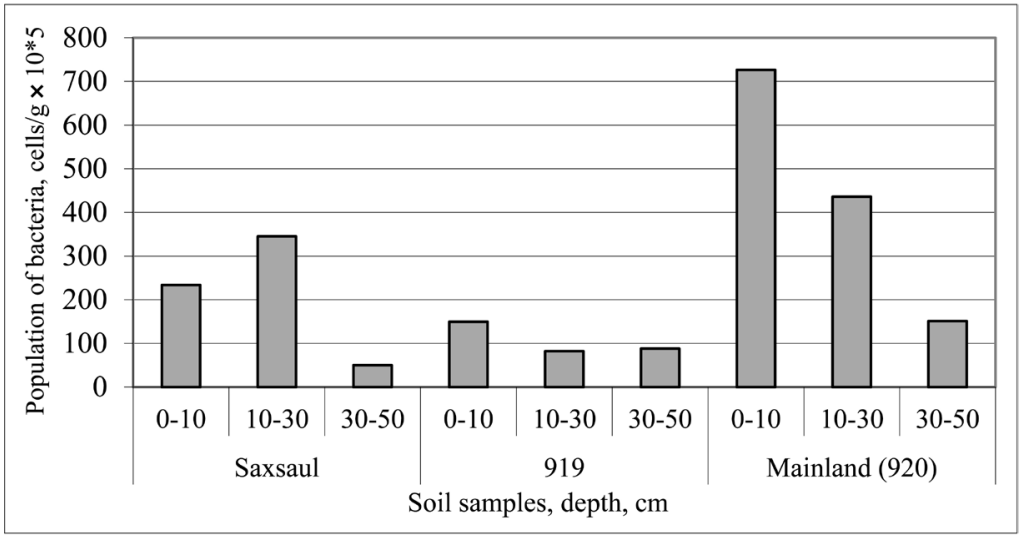

Figure 6. Total population of microorganisms in different parts of the soil cover on the dried seabed of the Aral Sea and on the mainland.

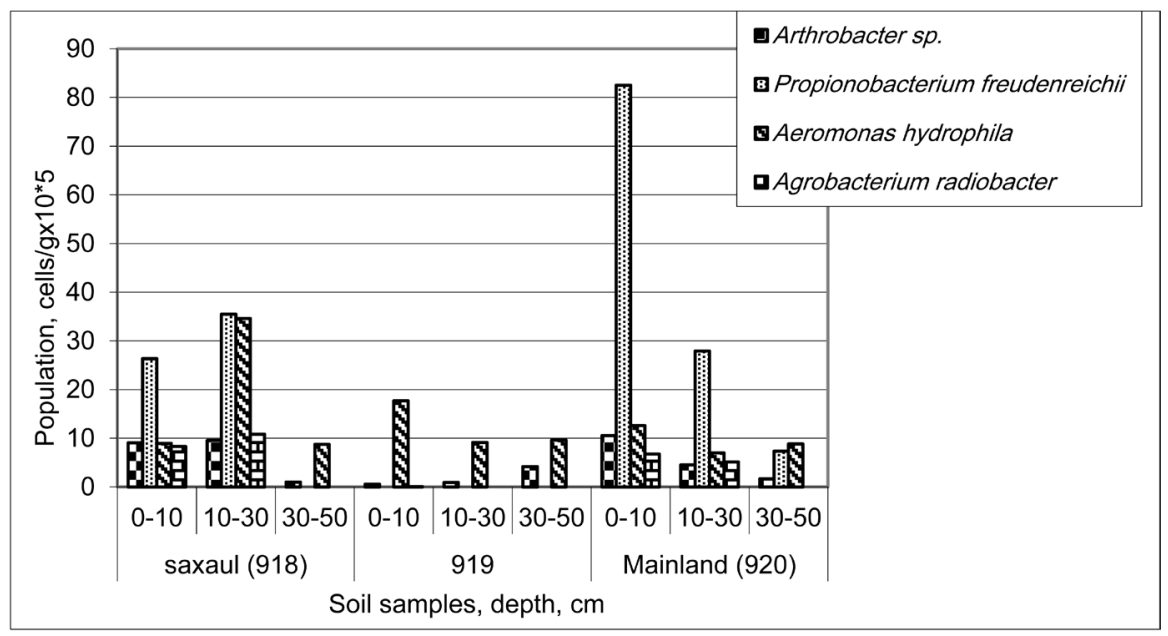

Figure 7. Contents of Aeromonas hydrophila, Arthrobacter sp., Propionibacterium freudenreichii and Agrobacterium radiobacter in different parts of the soil cover on the dried seabed of the Aral Sea and on the mainland.

For the analysis, we selected four species of typical soil bacteria, such as aerobes Arthrobacter sp. and Agrobacterium radiobacter, optionally anaerobe Aeromonas hydrophila and anaerobe Propionibacterium freudenreichii. The population of Propionibacterium freudenreichii is substantially higher in the upper soil layer on the mainland as compared to the soil under saxaul. Population of other soil species under consideration is comparable with that on the mainland and in the soil under saxaul. The soil in the deeper layer $(10-30 \mathrm{~cm})$ under brush is richer in those species than the mainland, perhaps, due to exudates of saxaul roots that microorganisms use for their development and reproduction. The population of Aeromonas hydrophila only on the bare land is comparable with other soil conditions. To find a contribution of those species to the soil formation process, let's examine their metabolic abilities.

Aeromonas hydrophila is a standard representative of the worm's digestive system (particularly, Eisenia foetida) (Marialigeti, 1979) that, supposedly, is a part, as a eukaryotic organism, of initial stages of the soil formation process. 
This class is capable of nitrogen fixation. In our study, the presence of eukaryotic organisms is confirmed by cholesterol, the chemical marker for these organisms (Tables 1-5).

Propionibacterium freudenreichii can destruct autochthonous organic matter in the soil and extract nitrogen from it (Benz et al., 1998). The increased population of this species in the soil on the mainland and its comparable population in the soil cover under saxaul indicated to accumulation of humus under bushes. Thus, one may conclude that there is the humus accumulation process under plants.

Arthrobacter sp. is a typical soil species, which belongs to autochthonous microorganisms, i.e. it can use soil organic matter. Particularly, this species destructs chitin-homopolymeric carbonhydrate-which is the main component of innertabrates' exoskeleton. The enormous amount of this species is present in the seawater as a component of zooplankton and in the soil, where it is formed by arthropoda, protozoa and fungi (Lengeler et al., 2005). The Arthrobacter type bacteria contribute to degradation of hydrocarbon compounds. Literature sources indicate that this type of bacteria can initiate the growth of plants, also thanks to production of phytohormones (Katsnelson \& Sirois, 1961; Katsnelson et al., 1962). In case of shortage of potassium, exometabolites of Arthrobacter sp. help potassium to pass into solution that is important for sandy soil. The above-listed metabolic features of this species seem to determine its key role at the first stages of the soil formation process on the dried seabed of the Aral Sea, where the association Aeromonas hydrophila-Arthrobacter sp. predominates.

Agrobacterium sp. is a typical microorganism, which forms associations with higher organisms, particularly, with plants. It is reproduced in rhizosphere by the released phyto-assimilates. These are Agrobacterium cultures that make plant cells divide and synthesize carbon and nitrogen sources for reproduction and survival of the bacterium itself, i.e. maintain the so called 'molecular farming'. The bacterium can live in saline habitats because of specific osmoregulatory substances that are accumulated in cells and keep minimal required water in the cytoplasm (Lengeler et al., 2005). The bacterium also demonstrates antifungal activity in vitro (Kerr, 1999). These metabolic features of agrobacteria define their role in the soil under saxaul and on the mainland. However, Agrobacterium sp. is not found in quantities that are enough for detection by GC-MS in the first stages of the soil formation process on the desert area of the dried seabed (Figure 4 \& Figure 5).

Two types of bacteria were found in the community of microorganisms in all studied profiles. Those are the Deinococcus ( $D$. deserti, D. radiophilus) type bacteria that are highly resistant to radiation [Modern microbiology, 2005] and that were described under conditions of the Sahara Desert (Groot et al.,2005) and the Hymenobacter and Pontibacter type bacteria that were identified in Chinese deserts (Zhang et al., 2009; Zhou et al., 2007). In terms of microbiology, this testifies that the studied soil belongs to desert type.

The content of micromycetes is higher in the soil under saxaul (Tables 1-5). 
Table 1. Composition of the community of microorganisms in the soil of Aral Sea-profiles 901-905 (samples 1 - 15), population of microorganisms cells/g $\times 10^{5}$.

\begin{tabular}{|c|c|c|c|c|c|c|c|c|c|c|c|c|c|c|c|}
\hline \multirow{3}{*}{\begin{tabular}{|l} 
No. profile \\
Depth,cm
\end{tabular}} & \multirow{2}{*}{\multicolumn{3}{|c|}{901}} & \multirow{2}{*}{\multicolumn{3}{|c|}{$\begin{array}{c}902 \\
\text { under saxaul }\end{array}$}} & \multirow{2}{*}{\multicolumn{3}{|c|}{903}} & \multirow{2}{*}{\multicolumn{3}{|c|}{$\frac{904}{\text { under saxaul }}$}} & \multirow{2}{*}{\multicolumn{3}{|c|}{905}} \\
\hline & & & & & & & & & & & & & & & \\
\hline & $0-10$ & $10-30$ & $30-50$ & $0-10$ & $10-30$ & $30-50$ & $0-10$ & $10-30$ & $30-50$ & $0-10$ & $10-30$ & $30-50$ & $0-10$ & $10-30$ & $30-50$ \\
\hline & \multicolumn{15}{|c|}{ Proteobacteria } \\
\hline Acetobacter-Rhodobacter group & 3.46 & 2.02 & 2.34 & 2.91 & 2.44 & 2.17 & 4.73 & 2.2 & 3.84 & 3.56 & 5.61 & 4.12 & 1.03 & 3.12 & 3.22 \\
\hline Aeromonas hydrophila & 4.15 & 3.09 & 8.85 & 0 & 7.34 & 3.14 & 6.05 & 1.76 & 14.69 & 1.23 & 0 & 2.55 & 0.18 & 0 & 0 \\
\hline Agrobacterium radiobacter & 2.33 & 2.47 & 1.5 & 2.99 & 0 & 0 & 0 & 0 & 0 & 2.14 & 7.46 & 6.61 & 0.5 & 3.41 & 6 \\
\hline Burkholderia cepacia & 1.9 & 0 & 0.01 & 3.83 & 0.42 & 0 & 1.19 & 0 & 0.36 & 0.86 & 2.51 & 0 & 0.12 & 6.05 & 2.19 \\
\hline Caulobactersp. & 0 & 0 & 0.31 & 0.26 & 0.1 & 0 & 1.31 & 0 & 0 & 0.83 & 1.31 & 0 & 0.33 & 2.36 & 0.79 \\
\hline Deinococcus radiophilus & 3.07 & 6.49 & 4.91 & 0 & 3.3 & 5.37 & 4.99 & 3.64 & 11.52 & 7.79 & 13.22 & 0 & 9.94 & 4.08 & 4.25 \\
\hline Desulfovibrio & 1.25 & 0 & 0 & 10.02 & 0 & 0 & 0 & 0.18 & 0 & 0 & 0 & 0 & 0 & 9.66 & 0 \\
\hline FeRed & 0 & 0 & 0 & 0 & 0 & 0 & 0 & 0 & 0 & 0 & 0.34 & 0 & 0 & 0 & 0 \\
\hline $\begin{array}{c}\text { Nitrobacter, Hyphomicrobium, } \\
\text { Xanthobacter+ }\end{array}$ & 0 & 0 & 0 & 2.24 & 0 & 0 & 0 & 0 & 0 & 0.76 & 0 & 0 & 0.59 & 7.69 & 0.74 \\
\hline Pseudomonas fluorescens & 0.56 & 0.39 & 0.42 & 0.42 & 0.45 & 0.51 & 0.76 & 0 & 0.7 & 0.37 & 0.8 & 0.67 & 0.26 & 0.4 & 0.46 \\
\hline Pseudomonas putida & 1.19 & 0 & 0.75 & 0.9 & 1.05 & 0 & 0.91 & 0 & 0 & 0 & 0 & 0 & 0.66 & 1.48 & 1.14 \\
\hline Pseudomonas vesicularis & 1.08 & 0.68 & 0.86 & 0.64 & 1.11 & 0.86 & 1.23 & 0.65 & 1.4 & 0.63 & 1.23 & 1.23 & 0.51 & 0.71 & 0.7 \\
\hline Sphingomonas adgesiva & 0.73 & 0.42 & 0.45 & 0.81 & 0.73 & 0.66 & 0.73 & 0.57 & 1.45 & 1.36 & 1.59 & 1.66 & 0.7 & 0.54 & 1.34 \\
\hline Sphingomonas capsulata & 3.49 & 2.37 & 3.52 & 1.84 & 2.34 & 4.61 & 2.02 & 3.14 & 6.77 & 1.24 & 2.53 & 4.39 & 0.27 & 0.66 & 1.26 \\
\hline$W A R B^{\star}$ & 0.56 & 0.4 & 0 & 0 & 1.11 & 1.02 & 1.43 & 1.16 & 1.35 & 1.22 & 0.9 & 0.76 & 0.32 & 0.27 & 0 \\
\hline \multirow[t]{2}{*}{ Xanthomonas sp. } & 0 & 0 & 0.56 & 0 & 0.73 & 0.27 & 0.83 & 0.29 & 0.57 & 0.27 & 0.46 & 0 & 0.43 & 0.26 & 0.5 \\
\hline & \multicolumn{15}{|c|}{ Actinobacteria } \\
\hline Actinomadura roseola & 0 & 0 & 0 & 0.07 & 0 & 0 & 0 & 0 & 0 & 0 & 0.22 & 0 & 0 & 0.56 & 0.07 \\
\hline Actinomyces sp. & 0 & 9.54 & 13.72 & 11.62 & 0 & 0 & 0 & 0 & 0 & 19.33 & 7.78 & 0 & 0 & 6.31 & 3.19 \\
\hline Arthrobacter sp. & 3.31 & 0.92 & 1.3 & 4.17 & 2.26 & 1.77 & 3.03 & 1.7 & 1.85 & 1.92 & 5.45 & 2.46 & 0.83 & 7.32 & 4.23 \\
\hline Bifidobacterium sp. & 0 & 0 & 0 & 0 & 0 & 0 & 0.09 & 0 & 0 & 0 & 0 & 0 & 0 & 5.91 & 0.12 \\
\hline Cellulomonas sp. & 5.47 & 1.79 & 1.86 & 3.04 & 2.85 & 3.49 & 1.19 & 2.37 & 2.35 & 3.87 & 2.97 & 3 & 2.21 & 8.22 & 4.03 \\
\hline Corynebacterium sp. & 0 & 0.19 & 0.35 & 0 & 0.27 & 0.35 & 0.42 & 0.32 & 0.71 & 0 & 1.82 & 0.77 & 0.07 & 0 & 0.69 \\
\hline Mycobacterium sp. & 2.7 & 2.16 & 0.53 & 6.39 & 0 & 0 & 0 & 0 & 0 & 0 & 0 & 8.92 & 0.37 & 0 & 8.9 \\
\hline Nocardia sp. & 0 & 0 & 0 & 1.7 & 0 & 0 & 0 & 0 & 0 & 0 & 0 & 0 & 0.69 & 2.89 & 0 \\
\hline Nocardia carnea & 0 & 0 & 0 & 0 & 0.56 & 0.59 & 0.46 & 0.43 & 0.79 & 1.11 & 0.92 & 0 & 0.51 & 0 & 1.9 \\
\hline Nocardiopsis sp. & 0.82 & 0.41 & 0.36 & 0.97 & 1.35 & 1.07 & 1.88 & 0.81 & 1.48 & 3.01 & 4.29 & 1.44 & 0.3 & 1.59 & 0.97 \\
\hline Propionibacterium freudenreichii & 0 & 0 & 2.35 & 3.24 & 5.84 & 3.25 & 4.62 & 7.56 & 8.82 & 0 & 11.68 & 8.67 & 1.94 & 14.01 & 4.33 \\
\hline Propionibacterium+ & 0.89 & 0.43 & 0 & 0 & 0.07 & 0 & 0.33 & 0.56 & 0 & 0 & 0 & 1.23 & 0 & 0 & 0.47 \\
\hline Rhodococcus equi & 4.1 & 0.96 & 1 & 1.09 & 4.21 & 0.77 & 20.02 & 2.21 & 4.96 & 2.28 & 3.7 & 3.89 & 1.86 & 4.79 & 3 \\
\hline
\end{tabular}




\section{Continued}

\begin{tabular}{|c|c|c|c|c|c|c|c|c|c|c|c|c|c|c|c|}
\hline Rhodococcus terrae & 0 & 0 & 1.18 & 0.72 & 0 & 0 & 0 & 0 & 0 & 1.2 & 0 & 0 & 1.22 & 4.92 & 0.93 \\
\hline Streptomyces-Nocardiopsis & 2.37 & 0.25 & 0.98 & 3.28 & 0.6 & 0.98 & 2.97 & 1.64 & 2.63 & 0 & 3.77 & 2.64 & 0.07 & 3.51 & 2.3 \\
\hline & \multicolumn{15}{|c|}{ Firmicutes } \\
\hline Bacillus sp. & 0 & 0.29 & 0.56 & 0 & 0 & 0 & 1.31 & 0.25 & 0 & 0 & 0.64 & 0 & 0 & 0 & 0 \\
\hline Bacillus subtilis & 0 & 0.11 & 0.08 & 0 & 0 & 0 & 0.27 & 0 & 0 & 0 & 0 & 0 & 0.17 & 1.02 & 0.44 \\
\hline Butyrivibrio 1-2-13 & 0 & 1.99 & 4.3 & 0.6 & 4.16 & 3.47 & 4.33 & 2.15 & 4.6 & 0.58 & 2.22 & 4.6 & 0.44 & 1.26 & 2.46 \\
\hline Butyrivibrio 1-4-11 & 0 & 0 & 0 & 0 & 0 & 0 & 2.66 & 0 & 0 & 0 & 0 & 0 & 0 & 2.42 & 0 \\
\hline Butyrivibrio 7 S-14-3 & 0 & 0 & 0 & 0 & 0 & 0 & 1.63 & 0 & 0 & 0 & 0 & 0 & 0 & 4.51 & 2.15 \\
\hline Clostridium perfringens & 0.1 & 0.13 & 0.19 & 0.16 & 0.05 & 0.05 & 0.1 & 0.09 & 0.14 & 0.19 & 0.22 & 0.17 & 0.04 & 0.06 & 0.07 \\
\hline Carboxydotermus & 1.3 & 2.68 & 4.54 & 1.07 & 5.47 & 4.48 & 3.21 & 3.06 & 8.33 & 25.26 & 5.74 & 4.9 & 2.27 & 0 & 7.01 \\
\hline Clostridium $O P A^{* *}$ & 0 & 0 & 0 & 2.24 & 0 & 0 & 0 & 0 & 0 & 1.09 & 3.1 & 0 & 1.45 & 6.29 & 1.19 \\
\hline Eubacterium sp. & 0.09 & 0 & 0 & 0.39 & 0.09 & 0 & 0.05 & 0 & 0.05 & 0.05 & 0.31 & 0.08 & 0.13 & 0.32 & 0.12 \\
\hline Eubacterium lentum & 0 & 1.13 & 1.72 & 0 & 2.86 & 1.43 & 2.21 & 1.19 & 2.69 & 4.23 & 1.15 & 1.91 & 0.68 & 0.88 & 1.89 \\
\hline Peptostreptococcus sp. & 9.06 & 9 & 7.61 & 5.84 & 9.14 & 7.37 & 9.7 & 6.76 & 13.67 & 6.62 & 16.78 & 20.4 & 0.66 & 1.11 & 1.95 \\
\hline Ruminococcus/Protozoa & 0 & 4.99 & 0 & 0 & 0 & 0 & 0 & 0 & 9.02 & 0 & 0 & 0 & 0 & 0 & 0 \\
\hline \multirow[t]{2}{*}{ Streptococcus mutans } & 0 & 0.11 & 0.21 & 0.11 & 0 & 0 & 0 & 0 & 0 & 0.18 & 0 & 0 & 0 & 0.16 & 0 \\
\hline & \multicolumn{15}{|c|}{ Bacteroidetes } \\
\hline Bacteroides hypermegas & 0 & 0 & 0 & 0 & 0 & 0 & 0 & 0 & 0 & 0 & 0 & 0 & 0.06 & 0.05 & 0 \\
\hline Bacteroides ruminicola & 0.54 & 0.3 & 0.42 & 0.65 & 0.28 & 0.38 & 0.51 & 0 & 0.88 & 0.45 & 0.73 & 1.07 & 0.2 & 0.35 & 0.58 \\
\hline Cytophaga sp. & 0.51 & 0.23 & 0.34 & 0.19 & 0.34 & 0.29 & 0.44 & 0.17 & 0.4 & 0.19 & 0.28 & 0.34 & 0.09 & 0.2 & 0.29 \\
\hline Hymenobacter, Pontibacter & 0.69 & 0.78 & 2.11 & 2.5 & 0.22 & 0 & 0.87 & 1.83 & 0.6 & 0.61 & 1.78 & 0.94 & 0.04 & 0.46 & 0.52 \\
\hline Hymenobacter/FRB & 2.3 & 0 & 0 & 3.95 & 0.6 & 0 & 0 & 0.01 & 0 & 6.01 & 9.05 & 0 & 0.25 & 93.87 & 7.77 \\
\hline Riemirella sp. & 0 & 0 & 0.38 & 0.73 & 0.58 & 3.59 & 0.95 & 0 & 0.84 & 5.88 & 1.2 & 0 & 0 & 0.42 & 0 \\
\hline Sphingobacterium spiritovorum & 0.23 & 0.05 & 0.11 & 0.17 & 0.35 & 0.28 & 0.57 & 0.2 & 0.43 & 0.1 & 0.7 & 0.41 & 0.04 & 0.32 & 0.35 \\
\hline
\end{tabular}

\section{Deinococcus-Thermus}

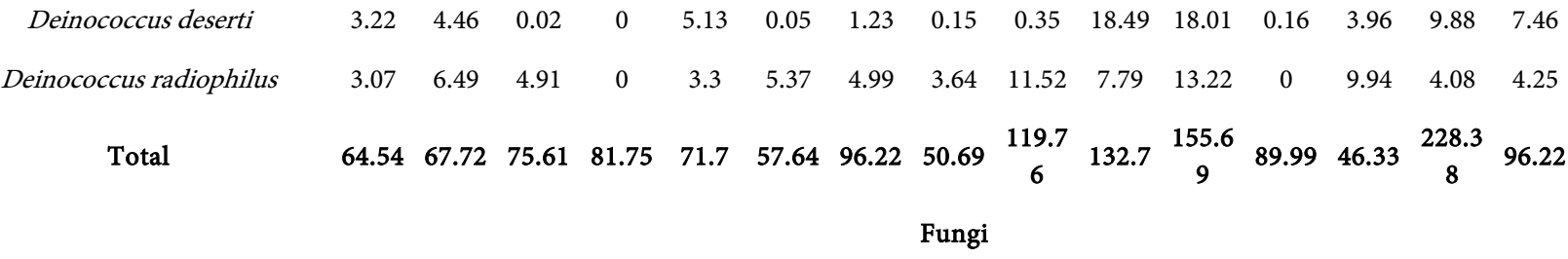

Glomus etunicatum (arbuscular micorhiza-AM fungi)

Fungi $18: 2 \mu \mathrm{g} / \mathrm{g}$

\begin{tabular}{ccccccccccccccccc}
0 & 0 & 0 & 5.92 & 0 & 0 & 0 & 0 & 0 & 0.37 & 0 & 0 & 0 & 0.78 & 0 \\
4.97 & 2.2 & 2.17 & 1.01 & 0 & 0 & 1.23 & 0 & 0 & 50.48 & 2.08 & 1.25 & 1.17 & 3.29 & 1.86 \\
& & & & \multicolumn{10}{c}{ Eucariotes } \\
0.21 & 0.15 & 0.11 & 0.18 & 0 & 0 & 0 & 0 & 0 & 0.12 & 0.36 & 0.32 & 0.08 & 0.07 & 0.08
\end{tabular}

Note: ${ }^{\star W o l i n e l l a-A c h o l e p l a s m a-R o s e o m o n a s-B u r k h o l d e r i a ; ~}{ }^{\star *}$ Clostridium omelianskii, C. pasterianum, C. acetobutyricum. 
Table 2. Composition of the community of microorganisms in the soil of Aral Sea-profiles 906-910 (16 - 30), population of microorganisms cells/g $\times 10^{5}$.

\begin{tabular}{|c|c|c|c|c|c|c|c|c|c|c|c|c|c|c|c|}
\hline \multirow{3}{*}{$\begin{array}{l}\text { No. profile } \\
\text { Depth,cm }\end{array}$} & & 906 & & \multirow{2}{*}{\multicolumn{3}{|c|}{907}} & \multirow{2}{*}{\multicolumn{3}{|c|}{908}} & \multicolumn{3}{|c|}{909} & \multirow{2}{*}{\multicolumn{3}{|c|}{910}} \\
\hline & \multicolumn{3}{|c|}{ near saxaul } & & & & & & & \multicolumn{3}{|c|}{ near saxaul } & & & \\
\hline & $0-10$ & $10-30$ & $30-50$ & $0-10$ & $10-30$ & $30-50$ & $0-10$ & $10-30$ & $30-50$ & $0-10$ & $10-30$ & $30-50$ & $0-10$ & $10-30$ & $30-50$ \\
\hline & \multicolumn{15}{|c|}{ Proteobacteria } \\
\hline Acetobacter-Rhodobacter group & 6.35 & 0.94 & 1.72 & 1.54 & 2.01 & 4.15 & 1.39 & 1.75 & 2.24 & 4.75 & 1.37 & 2.55 & 1.37 & 2.14 & 8.86 \\
\hline Aeromonas hydrophila & 4.32 & 0.71 & 1.41 & 1.44 & 3.31 & 0 & 1.8 & 2.78 & 1.92 & 3.03 & 1.68 & 3.28 & 5.45 & 3 & 1.28 \\
\hline Agrobacterium radiobacter & 2.7 & 2.46 & 2.35 & 3.15 & 2.66 & 9.87 & 2.51 & 1.3 & 2.2 & 0 & 6.32 & 5.97 & 4.95 & 3.77 & 7.82 \\
\hline Burkholderia cepacia & 0.37 & 0.04 & 0.39 & 0 & 0 & 7.88 & 0 & 0 & 0.48 & 0 & 0 & 0 & 0 & 0 & 0 \\
\hline Caulobacter sp. & 0.64 & 0 & 0 & 0 & 0 & 0.55 & 0.18 & 0 & 0.83 & 0 & 0 & 0 & 0 & 0 & 0.97 \\
\hline Desulfovibrio sp. & 4.93 & 0 & 0 & 0 & 0 & 11.87 & 0 & 0 & 2.13 & 5.38 & 0 & 0 & 0 & 0 & 0 \\
\hline $\begin{array}{c}\text { Nitrobacter, Hyphomicrobium, } \\
\text { Xanthobacter+ }\end{array}$ & 0 & 0.08 & 0 & 0 & 0 & 4.4 & 0 & 0 & 0 & 1.6 & 2.54 & 0 & 0 & 0 & 0 \\
\hline Pseudomonas fluorescens & 2.25 & 0.3 & 0.26 & 0.56 & 0.58 & 0.38 & 0.31 & 0.67 & 0.55 & 1.09 & 0.64 & 0.6 & 0.68 & 0.79 & 0.75 \\
\hline P.putida & 2.73 & 0.71 & 0.76 & 0.85 & 1.64 & 2.01 & 1.31 & 2.19 & 1.64 & 0 & 0.4 & 1.73 & 1.79 & 0.85 & 0.51 \\
\hline$P$. vesicularis & 1.7 & 0.51 & 0.55 & 0.89 & 0.67 & 1.46 & 0.52 & 1.01 & 0.75 & 1.45 & 1.07 & 1.23 & 1.32 & 1.3 & 0.85 \\
\hline Sphingomonas adgesiva & 3.29 & 1.08 & 0.69 & 0.9 & 0.38 & 1.77 & 0.52 & 0.72 & 0.73 & 0 & 0.41 & 0.95 & 0.48 & 1.08 & 1.5 \\
\hline Sphingomonas capsulata & 2.07 & 0.22 & 0.43 & 0.61 & 0.46 & 1.29 & 0.4 & 0.66 & 0.58 & 1.2 & 1.14 & 1.24 & 1 & 1.6 & 0.63 \\
\hline$W A R B^{\star}$ & 0.56 & 0.41 & 0.75 & 0.73 & 1.26 & 0.24 & 0.53 & 1.19 & 1.1 & 2.03 & 0.76 & 1.88 & 1.18 & 1.61 & 4.09 \\
\hline \multirow[t]{2}{*}{ Xanthomonas sp. } & 2.26 & 0.42 & 0.45 & 0.53 & 0.61 & 0.92 & 0.42 & 0.74 & 0.48 & 1.3 & 0.37 & 1.23 & 0.95 & 0.99 & 0.55 \\
\hline & \multicolumn{15}{|c|}{ Actinobacteria } \\
\hline Actinomadura roseola & 0 & 0 & 0 & 0 & 0 & 0.1 & 0 & 0 & 0 & 0 & 0 & 0 & 0 & 0 & 0 \\
\hline Actinomyces sp. & & 0 & 0 & 0 & 0 & 0 & 0 & 0 & 0 & 0 & 0 & 0 & 0 & 0 & 0 \\
\hline Arthrobactersp. & 2.97 & 0.77 & 1.2 & 1.23 & 1.05 & 10.68 & 0.83 & 1.22 & 1.64 & 4.97 & 1.37 & 2.81 & 1.58 & 2.46 & 1.3 \\
\hline Bifidobacterium sp. & 0.07 & 0.02 & 0.04 & 0.1 & 0.13 & 0 & 0.05 & 0.04 & 0.12 & 0 & 0 & 0 & 0 & 0 & 0.04 \\
\hline Cellulomonas sp. & 1.98 & 0.95 & 2.13 & 2.87 & 2.19 & 8.58 & 1.25 & 1.18 & 2.7 & 2.2 & 0.56 & 0 & 1.73 & 1.09 & 2.26 \\
\hline Corynebacterium sp. & 0.66 & 0.12 & 0.09 & 0 & 0 & 0.72 & 0.01 & 0 & 0 & 1.13 & 0 & 0.84 & 0 & 0.41 & 0.26 \\
\hline Mycobacterium sp. & 5.14 & 0 & 0 & 0 & 0 & 13.46 & 0 & 0 & 0 & 0 & 2.52 & 2.05 & 0 & 0 & 0 \\
\hline Nocardia sp. & 0 & 0 & 0 & 0 & 0 & 0 & 0 & 0 & 0 & 0 & 0 & 0 & 0 & 0 & 0 \\
\hline Nocardia carnea & 0 & 0 & 0.32 & 0.39 & 0.94 & 0 & 0 & 0 & 0.48 & 0 & 0 & 0 & 0 & 0 & 0.59 \\
\hline Nocardiopsis sp. & 1.03 & 0.36 & 0.47 & 0.56 & 0.54 & 1.86 & 0.4 & 0.39 & 4.08 & 0 & 0 & 0.58 & 0 & 0.49 & 0.99 \\
\hline $\begin{array}{l}\text { Propionobacterium } \\
\text { freudenreichii }\end{array}$ & 14.9 & 2.2 & 1.01 & 2.14 & 2.33 & 3.45 & 2.73 & 2.83 & 2.68 & 0 & 4.18 & 0 & 0 & 0 & 6.59 \\
\hline Propionibacterium sp. & 0 & 0.07 & 0.4 & 0.35 & 0.28 & 0 & 0.19 & 1.06 & 0 & 0 & 0.24 & 0.01 & 0.12 & 0 & 0 \\
\hline Rhodococcus equi & 7.51 & 2.17 & 3.19 & 3.03 & 2.9 & 3.72 & 1.3 & 2.84 & 2.63 & 3.37 & 1.09 & 1.22 & 1.64 & 4.38 & 4.9 \\
\hline
\end{tabular}




\section{Continued}

\begin{tabular}{|c|c|c|c|c|c|c|c|c|c|c|c|c|c|c|c|}
\hline Rhodococcus terrae & 5.26 & 1.81 & 0.76 & 0 & 0 & 0 & 0.55 & 4.08 & 3.58 & 0 & 0 & 0 & 0 & 0 & 0 \\
\hline Streptomyces sp. & 0.97 & 0.14 & 0.49 & 0 & 0 & 8.22 & 0.06 & 0 & 0.66 & 4.13 & 0 & 2.18 & 0.47 & 1.37 & 0.39 \\
\hline & \multicolumn{15}{|c|}{ Firmicutes } \\
\hline Bacillus subtilis & 0 & 0 & 0 & 0 & 0 & 0 & 0.13 & 0 & 0 & 0 & 0 & 0 & 0 & 0 & 0 \\
\hline Bacillus sp. & 0 & 0.28 & 0.29 & 0.36 & 0.76 & 0 & 0.27 & 0.84 & 0.37 & 0 & 0 & 0.12 & 0 & 0 & 0 \\
\hline Butyrivibrio 1-2-13 & 3.84 & 1.15 & 0.83 & 2.58 & 2.9 & 0 & 2 & 3.13 & 2.09 & 0 & 5.3 & 0 & 0 & 2.4 & 1.8 \\
\hline Butyrivibrio 1-4-11 & 1.66 & 0 & 0.32 & 0.83 & 1.49 & 0 & 0.61 & 2.63 & 0.75 & 0 & 2.14 & 0 & 0 & 0 & 0 \\
\hline Butyrivibrio $7 S-14-3$ & 4.11 & 0.4 & 0.74 & 1.88 & 2.34 & 0 & 1.45 & 1.7 & 2.23 & 0 & 0 & 0 & 0 & 0 & 0.67 \\
\hline Carboxydotermus sp. & 7.9 & 3.23 & 1.35 & 1.85 & 0.99 & 1.12 & 2.2 & 0 & 1.9 & 4.49 & 1.87 & 2.39 & 0.71 & 4.13 & 8.89 \\
\hline Clostridium $O P A^{\star *}$ & 0 & 0 & 0 & 0 & 0 & 4.43 & 0 & 0 & 0 & 0 & 0 & 0 & 0 & 0 & 0 \\
\hline C.perfringens & 0.16 & 0.05 & 0.04 & 0.04 & 0.05 & 0.09 & 0.04 & 0.07 & 0.06 & 0.11 & 0.08 & 0.07 & 0.05 & 0.09 & 0.07 \\
\hline Eubacterium lentum & 2.36 & 0.91 & 0.54 & 1.67 & 1.63 & 0 & 1.33 & 1.78 & 1.75 & 1.92 & 1.74 & 1.73 & 0 & 0.45 & 3.08 \\
\hline Eubacterium sp. & 1.79 & 0 & 0.07 & 0.05 & 0.12 & 0.04 & 0.13 & 0.05 & 0.05 & 0 & 0.17 & 0 & 0.06 & 0 & 0.04 \\
\hline Peptostreptococcus sp. & 5.78 & 0.96 & 0.66 & 0.92 & 1.66 & 3.09 & 1.08 & 1.9 & 2.31 & 0 & 1.57 & 0 & 0 & 0 & 0 \\
\hline Ruminococcus sp. & 9.03 & 2.18 & 2.07 & 4.79 & 1.6 & 9.19 & 3.22 & 8.04 & 1.47 & 20.15 & 3.74 & 0 & 3.8 & 6 & 0 \\
\hline \multirow[t]{2}{*}{ Streptococcus mutans } & 0 & 0 & 0 & 0 & 0 & 0 & 0 & 0 & 0 & 0 & 0 & 0 & 0 & 0 & 0 \\
\hline & \multicolumn{15}{|c|}{ Bacteroidetes } \\
\hline Bacteroides hypermegas & 0.44 & 0 & 0 & 0 & 0 & 0.45 & 0.08 & 0.14 & 0 & 0 & 0.04 & 0 & 0.13 & 0 & 0 \\
\hline Bacteroides ruminicola & 1.66 & 0.27 & 0.3 & 0 & 0.35 & 0.65 & 0.34 & 0.48 & 0.31 & 0 & 0 & 0 & 0.38 & 0 & 0.5 \\
\hline Cytophaga sp. & 0.94 & 0.15 & 0.25 & 0.18 & 0.39 & 0.41 & 0.2 & 0.46 & 0.36 & 0.61 & 0.3 & 0.6 & 0.5 & 0.43 & 0.2 \\
\hline Hymenobacter, Pontibacter & 1.26 & 0.02 & 0 & 0 & 0 & 1.82 & 0 & 0 & 0 & 0 & 0 & 0 & 0 & 0 & 0.55 \\
\hline Hymenobacter/FRB & 1.38 & 0.45 & 0 & 0 & 0 & 14.76 & 0 & 0.67 & 0 & 1.56 & 0 & 0 & 0 & 2.09 & 2.53 \\
\hline Riemirella sp. & 1.56 & 0 & 0.31 & 0 & 0.46 & 1.91 & 0 & 0 & 0.86 & 0 & 0 & 0 & 0 & 0 & 0 \\
\hline Sphingobacterium spiritovorum & 0.8 & 0.04 & 0.14 & 0.1 & 0.11 & 0.46 & 0.07 & 0.14 & 0.2 & 0.29 & 0.13 & 0.27 & 0 & 0.16 & 0.14 \\
\hline & \multicolumn{15}{|c|}{ Deinococcus-Thermus } \\
\hline Deinococcus deserti & 9.95 & 2.58 & 3.32 & 4.29 & 5.18 & 0 & 3.4 & 6 & 6.31 & 0.24 & 4.9 & 0.06 & 1.95 & 0.31 & 7.5 \\
\hline Deinococcus radiophilus & 7.71 & 0 & 3.21 & 4.89 & 2.3 & 6.83 & 5.43 & 4.77 & 4.26 & 0 & 1.11 & 0 & 0 & 0 & 4.23 \\
\hline \multirow[t]{2}{*}{ Total population } & 29.16 & 34.3 & 46.3 & 46.27 & $\begin{array}{c}142.8 \\
3\end{array}$ & 39.24 & 59.45 & 59.48 & 67 & 49.75 & 35.59 & 32.29 & 43.39 & 75.33 & 29.16 \\
\hline & \multicolumn{15}{|c|}{ Fungi } \\
\hline Fungi $18: 2, \mu \mathrm{g} / \mathrm{g}$ & 2.11 & 0.39 & 0.24 & 0.61 & 0.61 & 4.73 & 0 & 0 & 0.66 & 0 & 0 & 0 & 0 & 0 & 3.39 \\
\hline \multicolumn{16}{|l|}{ AM fungi } \\
\hline \multirow[t]{3}{*}{ Glomus etunicatum } & 0 & 0 & 0 & 0 & 0 & 0 & 0 & 0 & 0 & 0 & 0 & 0 & 0 & 0 & 0 \\
\hline & \multicolumn{15}{|c|}{ Eucariotes } \\
\hline & 0.29 & 0.04 & 0 & 0.11 & 0 & 0.07 & 0 & 0 & 0 & 0 & 0 & 0 & 0 & 0 & 0.12 \\
\hline
\end{tabular}


Table 3. Composition of the community of microorganisms in the soil of Aral Sea-profiles 911-915 (31 - 45), population of microorganisms cells/g $\times 10^{5}$.

\begin{tabular}{|c|c|c|c|c|c|c|c|c|c|c|c|c|c|c|c|}
\hline \multirow{2}{*}{ No. profile } & \multirow{2}{*}{\multicolumn{3}{|c|}{911}} & \multirow{2}{*}{\multicolumn{3}{|c|}{912}} & \multicolumn{3}{|c|}{913} & \multicolumn{3}{|c|}{914} & \multirow{2}{*}{\multicolumn{3}{|c|}{915}} \\
\hline & & & & & & & \multicolumn{3}{|c|}{ Under saxaul bush } & \multicolumn{3}{|c|}{ Near saxaul bush } & & & \\
\hline \multirow[t]{2}{*}{ Depth,cm } & $0-10$ & $10-30$ & $30-50$ & $0-10$ & $10-30$ & $30-50$ & $0-10$ & $10-30$ & $30-50$ & $0-10$ & $10-30$ & $30-50$ & $0-10$ & $10-30$ & $30-50$ \\
\hline & \multicolumn{15}{|c|}{ Proteobacteria } \\
\hline Acetobacter-Rhodobacter group & 2.45 & 2.51 & 23.19 & 7.93 & & 0 & 60.15 & 101.03 & 11.79 & 2.62 & 14.75 & 9.26 & 50.21 & 5.86 & 27.56 \\
\hline Aeromonas hydrophila & 2.18 & 3.99 & 82.31 & 17.12 & & 1.44 & 0 & 47.65 & 2.16 & 0 & 0 & 0 & 0 & 0.08 & 14.27 \\
\hline Agrobacterium radiobacter & 1.34 & 0 & 0 & 0 & & 0 & 43.31 & 53.5 & 2.52 & 2.94 & 16.27 & 9.75 & 17.05 & 4 & 0 \\
\hline Burkholderia cepacia & 0 & 0 & 0 & 0 & & 0 & 28.13 & 41.84 & 0.73 & 0.97 & 20.28 & 16.31 & 13.37 & 0 & 0.52 \\
\hline Caulobacter sp. & 0 & 0 & 0 & 0 & & 1.44 & 13.29 & 24.78 & 3.44 & 1.41 & 8.09 & 2.88 & 18.09 & 1.2 & 0 \\
\hline Desulfovibrio sp. & 0 & 0 & 0 & 0 & & 0 & 0 & 0 & 0 & 0 & 0 & 4.24 & 0 & 9.52 & 0 \\
\hline $\begin{array}{c}\text { Nitrobacter, Hyphomicrobium, } \\
\text { Xanthobacter+ }\end{array}$ & 0 & 0.14 & 0 & 0 & & 0 & 0 & 0 & 0 & 0 & 0 & 14.94 & 16.4 & 0 & 0 \\
\hline Ochrobactrum sp. & 0 & 0 & 0 & 0 & & 0 & 0 & 0 & 0 & 0 & 0 & 0 & 0 & 0.8 & 0 \\
\hline Pseudomonas fluorescens & 1.02 & 0.95 & 8.13 & 2.62 & & 0 & 5.82 & 7.23 & 0.48 & 0.38 & 1.68 & 0.95 & 2.46 & 3.84 & 2.3 \\
\hline P.putida & 1.46 & 2.42 & 23.56 & 6.49 & & 0 & 0 & 0 & 0.8 & 0.69 & 0 & 0 & 0 & 1.16 & 3.4 \\
\hline$P$. vesicularis & 1.16 & 1.02 & 17.31 & 3.29 & & 0 & 9.04 & 20.38 & 1.02 & 0.59 & 2.46 & 1.09 & 4.24 & 0.97 & 3.31 \\
\hline Sphingomonas adgesiva & 1.12 & 1.14 & 0 & 0 & & 0 & 12.13 & 30.22 & 1.12 & 0.84 & 5.5 & 1.78 & 9.28 & 2.75 & 3.28 \\
\hline Sphingomonas capsulata & 0.8 & 1.5 & 8.94 & 3.67 & & 0.22 & 7.83 & 18.69 & 0.54 & 0.51 & 1.41 & 0.99 & 5.61 & 1.17 & 3.45 \\
\hline$W A R B^{\star}$ & 2.22 & 1 & 16.46 & 3.62 & & 0.01 & 20.89 & 33.04 & 2.28 & 0.08 & 3.7 & 0 & 6.64 & 1.15 & 4.69 \\
\hline \multirow[t]{2}{*}{ Xanthomonas sp. } & 0.83 & 1.19 & 15.85 & 3.53 & & 0 & 7.71 & 20.1 & 0.93 & 0.59 & 1.81 & 1.16 & 3.69 & 1.06 & 3.58 \\
\hline & \multicolumn{15}{|c|}{ Actinobacteria } \\
\hline Actinomadura roseola & 0 & 0 & 0 & 0 & & 0 & 0 & 0 & 0 & 0 & 0 & 0 & 0 & 0 & 0 \\
\hline Actinomyces sp. & 0 & 0 & 0 & 0 & & 0 & 0 & 57.98 & 3.86 & 3.74 & 7.24 & 9.88 & 32.78 & 0 & 0 \\
\hline Arthrobactersp. & 1.98 & 2.29 & 2.79 & 4 & & 5.06 & 25.87 & 36.96 & 2.55 & 2.36 & 8.16 & 15.67 & 19.2 & 3.9 & 8.89 \\
\hline Bifidobacterium sp. & 0 & 0 & 0 & 0 & & 0.3 & 0.47 & 0 & 0 & 0.2 & 1.68 & 0 & 0 & 0.31 & 0.24 \\
\hline Cellulomonas sp. & 1.45 & 1.42 & 5.27 & 1.19 & & 14.12 & 0 & 0 & 1.69 & 4.18 & 0 & 18.2 & 7.13 & 5.36 & 11.06 \\
\hline Corynebacterium sp. & 0.88 & 0.87 & 2.67 & 1.95 & & 0.44 & 10.36 & 19.58 & 0 & 0 & 0 & 0.1 & 11.61 & 0.2 & 0.14 \\
\hline Mycobacterium sp. & 0 & 0 & 0 & 0 & & 30.24 & 0 & 0 & 0 & 0 & 0 & 0 & 0 & 0 & 0 \\
\hline Nocardia sp. & 0 & 0 & 0 & 0 & & 0 & 0 & 0 & 1.13 & 0.62 & 0 & 3.24 & 0 & 0 & 0 \\
\hline Nocardia carnea & 0 & 0 & 0 & 0 & & 2.82 & 0 & 0 & 0 & 0 & 3.77 & 4.99 & 9.22 & 1.04 & 0 \\
\hline Nocardiopsis sp. & 0 & 0 & 0 & 0 & & 0 & 7.67 & 14.38 & 1.52 & 0.74 & 3.75 & 3.9 & 8.84 & 1.39 & 1.7 \\
\hline $\begin{array}{l}\text { Propionobacterium } \\
\text { freudenreichii }\end{array}$ & 0 & 0 & 0 & 0 & & 0 & 0 & 190.49 & 15.57 & 5.36 & 38.03 & 14.83 & 64.34 & 8.79 & 11.46 \\
\hline Propionibacterium sp. & 0.35 & 0 & 0 & 0 & & 1.78 & 1.61 & 0 & 0.41 & 0.1 & 2.14 & 0 & 0 & 0 & 2.62 \\
\hline
\end{tabular}




\section{Continued}

\begin{tabular}{|c|c|c|c|c|c|c|c|c|c|c|c|c|c|c|}
\hline Rhodococcus equi & 3.8 & 6.52 & 21.16 & 10.32 & 4.51 & 210.43 & 368.71 & 54.34 & 12.64 & 61.97 & 25.94 & 116.55 & 22.92 & 52.33 \\
\hline Rhodococcus terrae & 0 & 0 & 0 & 0 & 0 & 0 & 18.88 & 0 & 3.97 & 0 & 0 & 18.76 & 0 & 0 \\
\hline Streptomyces sp. & 1.45 & 2.13 & 4.27 & 2.32 & 0 & 12.06 & 12.12 & 0.35 & 0 & 0 & 4.29 & 11.28 & 1.03 & 0 \\
\hline & \multicolumn{14}{|c|}{ Firmicutes } \\
\hline Bacillus subtilis & 0 & 0 & 0 & 0 & 0.55 & 12.09 & 13.51 & 2.75 & 0.68 & 4.4 & 2.24 & 8.58 & 0.96 & 0 \\
\hline Bacillus sp. & 0 & 0 & 0 & 0 & 0 & 1.21 & 4.41 & 1.76 & 0.98 & 2.83 & 0 & 0 & 0 & 0.91 \\
\hline Butyrivibrio 1-2-13 & 0 & 0 & 0 & 0 & 0 & 0 & 52.99 & 9.16 & 5.58 & 19.95 & 0 & 14.91 & 5.52 & 11.28 \\
\hline Butyrivibrio 1-4-11 & 0 & 0 & 0 & 0 & 4.27 & 5.58 & 28.72 & 9.24 & 1.28 & 13.6 & 0 & 0 & 2.75 & 5.73 \\
\hline Butyrivibrio 7 S-14-3 & 0 & 0 & 0 & 0 & 5.62 & 17.12 & 78.58 & 13.37 & 4.05 & 33.37 & 0 & 0 & 6.75 & 7.87 \\
\hline Carboxydotermus sp. & 2 & 0 & 0 & 0 & 56.07 & 101.15 & 246.56 & 10.82 & 9.16 & 40.77 & 4.58 & 17.24 & 11.32 & 1.18 \\
\hline Clostridium $O P A^{\star}$ & 0 & 0 & 0 & 0 & 0.14 & 0 & 0 & 1.68 & 3.37 & 0 & 7.97 & 0 & 0 & 0 \\
\hline C.perfringens & 0.06 & 0.06 & 1.32 & 0.15 & 0 & 1.66 & 1.89 & 0.08 & 0.07 & 0.38 & 0.18 & 0.86 & 0.07 & 0.2 \\
\hline Eubacterium lentum & 1.89 & 4.31 & 49.78 & 14.99 & 28.76 & 0 & 0 & 5.48 & 5.28 & 12.85 & 0 & 0 & 7.97 & 5.78 \\
\hline Eubacterium sp. & 0 & 0 & 0 & 0 & 0 & 0.07 & 0.18 & 0.75 & 0.24 & 0.23 & 0.17 & 0.04 & 0.27 & 0.06 \\
\hline Peptostreptococcus sp. & 0 & 15.59 & 0 & 0 & 0 & 0 & 0 & 11.91 & 17.44 & 4.48 & 7.63 & 8.99 & 9.88 & 28.38 \\
\hline Ruminococcus sp. & 0 & 5.44 & 57.26 & 23.71 & 25.21 & 258.94 & 202.92 & 16.79 & 13 & 67.79 & 3.8 & 22.04 & 10.56 & 5.18 \\
\hline \multirow[t]{2}{*}{ Streptococcus mutans } & 0 & 0 & 0 & 0 & 0 & 0 & 0 & 30.81 & 0 & 48.23 & 0.19 & 126.05 & 0 & 0 \\
\hline & \multicolumn{14}{|c|}{ Bacteroidetes } \\
\hline Bacteroides hypermegas & 0 & 0 & 0 & 0.77 & 0 & 1.33 & 4.61 & 0.18 & 0.05 & 0.39 & 0.15 & 1.21 & 0.15 & 0.54 \\
\hline Bacteroides ruminicola & 0 & 0.8 & 8.97 & 2.58 & 0 & 6.54 & 18.06 & 0.94 & 0.87 & 1.51 & 1.12 & 3.86 & 0.38 & 1.84 \\
\hline Cytophaga sp. & 0.37 & 0.32 & 4.23 & 1.49 & 0 & 8.66 & 17.22 & 0.94 & 0.39 & 2.07 & 0.78 & 4.24 & 0.54 & 2.04 \\
\hline Hymenobacter, Pontibacter & 0 & 0.2 & 0 & 0 & 0 & 0 & 0 & 0.2 & 0 & 0 & 5.15 & 18.71 & 0.39 & 4.74 \\
\hline Hymenobacter/FRB & 0 & 2.31 & 0 & 0 & 3.6 & 0 & 0 & 0 & 1.94 & 0 & 30.23 & 0 & 0 & 0 \\
\hline Riemirella sp. & 0 & 0 & 0 & 0 & 0 & 0 & 0 & 0 & 0 & 0 & 2.94 & 11.47 & 0 & 0 \\
\hline \multirow[t]{2}{*}{ Sphingobacterium spiritovorum } & 0.24 & 0.15 & 1.75 & 0.83 & 0 & 3 & 4.65 & 0.24 & 0.21 & 0.61 & 0.58 & 2.26 & 0.55 & 1.95 \\
\hline & \multicolumn{14}{|c|}{ Deinococcus-Thermus } \\
\hline Deinococcus deserti & 0.27 & 0.46 & 1.48 & 0.72 & 25.99 & 92.15 & 125.18 & 17.74 & 13.18 & 45.21 & 42 & 92.12 & 16.79 & 31.96 \\
\hline Deinococcus radiophilus & 0 & 0 & 0 & 0 & 19.24 & 21.74 & 30.36 & 3.78 & 42.58 & 15.42 & 21.76 & 76.82 & 4.09 & 0.51 \\
\hline \multirow[t]{2}{*}{ Total } & 29.32 & 58.73 & 356.7 & 113.29 & 231.83 & 1008.01 & 1947.4 & 247.85 & 165.88 & 516.782 & 295.86 & 856.15 & 157.44 & 264.95 \\
\hline & \multicolumn{14}{|c|}{ Cyanobacteria } \\
\hline \multirow[t]{2}{*}{ Anabaena } & 0 & 0 & 0 & 0 & 0 & 16.03 & 26.73 & 0.54 & 0.62 & 4.82 & 1.27 & 10.37 & 0 & 0 \\
\hline & \multicolumn{14}{|c|}{ Fungi } \\
\hline Fungi $18: 2, \mu \mathrm{g} / \mathrm{g}$ & 0 & 0 & 0 & 0 & 8.3 & 16.87 & 14.94 & 1.69 & 0.55 & 8.83 & 7.79 & 44.62 & 1.65 & 1.56 \\
\hline Glomus etunicatum cells/g $\times 10^{5}$ & 0 & 0 & 0 & 0 & 0 & 0 & 0 & 0 & 0 & 0 & 3.78 & 18.04 & 1.36 & 0 \\
\hline
\end{tabular}


Table 4. Composition of the community of microorganisms in the soil of Aral Sea-profiles 916-920 (46 - 60), population of microorganisms cells $/ \mathrm{g} / \times 10^{5}$.

\begin{tabular}{|c|c|c|c|c|c|c|c|c|c|c|c|c|c|c|c|}
\hline \multirow{3}{*}{ No. profile } & \multirow{2}{*}{\multicolumn{3}{|c|}{916}} & \multicolumn{3}{|c|}{917} & \multicolumn{3}{|c|}{918} & \multirow{2}{*}{\multicolumn{3}{|c|}{919}} & \multicolumn{3}{|c|}{920} \\
\hline & & & & \multicolumn{3}{|c|}{ Near saxaul bush } & \multicolumn{3}{|c|}{ Near saxaul bush } & & & & \multicolumn{3}{|c|}{ Mainland } \\
\hline & $0-10$ & $10-30$ & $30-50$ & $0-10$ & $10-30$ & $30-50$ & $0-10$ & $10-30$ & $30-50$ & $0-10$ & $10-30$ & $30-50$ & $0-10$ & $10-30$ & $30-50$ \\
\hline & \multicolumn{15}{|c|}{ Proteobacteria } \\
\hline Acetobacter-Rhodobacter group & 5.94 & 2.26 & 9.36 & 2.3 & 3.18 & 9.15 & 18.22 & 21.68 & 4.29 & 22.41 & 10.55 & 5.82 & 51.78 & 21.9 & 7.6 \\
\hline Aeromonas hydrophila & 1.77 & 3.33 & 1.75 & 6.25 & 6.72 & 10.4 & 8.94 & 34.63 & 8.75 & 17.69 & 9.16 & 9.63 & 12.6 & 7.02 & 8.83 \\
\hline Agrobacterium radiobacter & 2.07 & 0.38 & 3.06 & 0 & 0 & 0 & 8.33 & 10.85 & 0 & 0.09 & 0 & 0 & 6.79 & 5.14 & 0 \\
\hline Burkholderia cepacia & 0.9 & 0.11 & 1.05 & 0 & 0 & 3.06 & 7.59 & 1.48 & 0 & 0 & 0 & 0 & 17.96 & 3.35 & 0 \\
\hline Caulobacter sp. & 1.22 & 0.51 & 1.27 & 0 & 0 & 3.12 & 0 & 2.46 & 1.38 & 0 & 0 & 0.35 & 2.22 & 3.78 & 2.18 \\
\hline Desulfovibrio sp. & 90.19 & 0 & 147.74 & 0 & 0 & 0 & 3.97 & 3.78 & 1.78 & 2.8 & 0 & 5.76 & 14.69 & 0 & 0 \\
\hline FeRed & 0 & 0 & 0.7 & 0 & 0 & 0 & 0 & 0 & 0 & 0 & 0 & 0 & 0 & 0 & 0 \\
\hline $\begin{array}{c}\text { Nitrobacter, Hyphomicrobium, } \\
\text { Xanthobacter+ }\end{array}$ & 0 & 0 & 0 & 0 & 0 & 7.08 & 0 & 0 & 0 & 0 & 0 & 2.07 & 0 & 7.26 & 1.87 \\
\hline Pseudomonas fluorescens & 0.52 & 0.48 & 0.8 & 1.99 & 1.41 & 1.55 & 2.75 & 6.2 & 0.87 & 0 & 0.89 & 1.14 & 7.07 & 3.16 & 2.2 \\
\hline P.putida & 1.1 & 1.33 & 1.24 & 1.72 & 2.09 & 9.6 & 2.17 & 0 & 2.15 & 0 & 1.91 & 4 & 7.07 & 0 & 1.85 \\
\hline$P$. vesicularis & 1.09 & 0.83 & 1.15 & 1.73 & 1.57 & 5.98 & 5.67 & 8.42 & 1.66 & 2.99 & 1.49 & 1.84 & 6.33 & 2.82 & 1.77 \\
\hline Sphingomonas adgesiva & 1.83 & 0.98 & 1.83 & 0 & 1.27 & 5.41 & 3.31 & 15.83 & 0.95 & 20.06 & 2.71 & 1.54 & 14.49 & 7.71 & 2.98 \\
\hline Sphingomonas capsulata & 1.25 & 0.64 & 1.19 & 1.92 & 1.6 & 2.79 & 2.36 & 7.86 & 1.22 & 5.92 & 1.79 & 2.45 & 12.62 & 3.8 & 1.69 \\
\hline$W A R B^{\star}$ & 1.99 & 1.1 & 1.49 & 2.02 & 1.63 & 2.25 & 3.66 & 12.12 & 1.69 & 2.09 & 2.57 & 0.99 & 18.58 & 5.65 & 4.27 \\
\hline \multirow[t]{2}{*}{ Xanthomonas sp. } & 1.58 & 1.14 & 1.22 & 1.59 & 1.48 & 1.46 & 5.42 & 7.77 & 3.1 & 3.35 & 2.65 & 2.87 & 10.02 & 4 & 2.69 \\
\hline & \multicolumn{15}{|c|}{ Actinobacteria } \\
\hline Actinomadura roseola & 0 & 0 & 0 & 0 & 0 & 0.03 & 0 & 0 & 0 & 0 & 0 & 0.08 & 0 & 0 & 0.14 \\
\hline Actinomyces sp. & 0 & 0 & 0 & 0 & 0 & 0 & 0 & 0 & 0.65 & 0 & 0 & 3.79 & 71.07 & 80.68 & 20.67 \\
\hline Arthrobacter sp. & 1.12 & 1.9 & 0 & 2.22 & 1.79 & 25.71 & 9.09 & 9.55 & 1.01 & 0.56 & 0.94 & 4.19 & 10.55 & 4.56 & 1.65 \\
\hline Bifidobacterium sp. & 0 & 0.11 & 0.36 & 0 & 0 & 0 & 0 & 0 & 0 & 0 & 0 & 0 & 0 & 0 & 0 \\
\hline Cellulomonas sp. & 7.97 & 1.98 & 6.67 & 2.44 & 2.27 & 31.54 & 0 & 0 & 0.56 & 0 & 0 & 0 & 0 & 6.43 & 0 \\
\hline Corynebacterium sp. & 0 & 0 & 0 & 0.46 & 0.45 & 1 & 0.27 & 4.39 & 0.19 & 1.34 & 0.84 & 0.44 & 2.46 & 0.96 & 0.47 \\
\hline Mycobacterium sp. & 0 & 0 & 0 & 0 & 0.25 & 3.9 & 0 & 0 & 0 & 0 & 0 & 0 & 16.63 & 0 & 8.93 \\
\hline Nocardia carnea & 0.73 & 0.4 & 0.93 & 0 & 0 & 0 & 0 & 0 & 0 & 0 & 0 & 0 & 11.01 & 0 & 2.16 \\
\hline Nocardiopsis sp. & 1.33 & 0.57 & 0.94 & 0 & 0 & 16.48 & 4.05 & 1.67 & 0.25 & 0 & 0 & 0.58 & 15.31 & 7.01 & 1.91 \\
\hline $\begin{array}{l}\text { Propionobacterium } \\
\text { freudenreichii }\end{array}$ & 4.74 & 3.29 & 6.08 & 0 & 2.27 & 0 & 26.35 & 35.49 & 0 & 0 & 0 & 0 & 82.56 & 27.91 & 7.35 \\
\hline Propionibacterium sp. & 0 & 0.4 & 0 & 0 & 0 & 0 & 0 & 0 & 0 & 0 & 0 & 0 & 0 & 0 & 0 \\
\hline Rhodococcus equi & 18.5 & 8.05 & 42.04 & 2.78 & 3.7 & 4.09 & 15.35 & 25.1 & 0.66 & 2.5 & 1.12 & 1.11 & 23.48 & 10.35 & 2.59 \\
\hline
\end{tabular}




\section{Continued}

\begin{tabular}{|c|c|c|c|c|c|c|c|c|c|c|c|c|c|c|c|}
\hline Rhodococcus terrae & 2.06 & 2.23 & 6 & 0 & 3.5 & 2.04 & 0 & 0 & 3.96 & 26.33 & 12.36 & 2.41 & 0 & 0 & 0 \\
\hline Streptomyces sp. & 0 & 0 & 0 & 0.94 & 0.84 & 5.25 & 4.9 & 10.19 & 0.85 & 2.49 & 0.76 & 3.33 & 16.73 & 0 & 1.61 \\
\hline \multicolumn{16}{|c|}{ Firmicutes } \\
\hline Bacillus subtilis & 0.58 & 0.36 & 0.74 & 0 & 0 & 0.56 & 0 & 1.55 & 0.2 & 0 & 0 & 0.38 & 0 & 0 & 1.02 \\
\hline Bacillus sp. & 0 & 0.45 & 0.31 & 0 & 0 & 0 & 0.09 & 0.04 & 0.84 & 0 & 0 & 0.85 & 3.5 & 0 & 0.57 \\
\hline Butyrivibrio 1-2-13 & 3.56 & 3.88 & 8.33 & 5.63 & 3.55 & 0 & 11 & 19.71 & 0 & 0 & 0 & 0.72 & 12.73 & 5.72 & 2 \\
\hline Butyrivibrio 1-4-11 & 1.95 & 1.77 & 5.63 & 0 & 0 & 0 & 6.26 & 0 & 0 & 0 & 0 & 0 & 0 & 0 & 0 \\
\hline Butyrivibrio 7 S-14-3 & 3.51 & 3.24 & 7.82 & 0 & 0 & 0 & 3.71 & 0 & 0 & 0 & 0 & 0 & 0 & 0 & 0 \\
\hline Carboxydotermus sp. & 7.45 & 2.41 & 7.16 & 2.28 & 1.98 & 0 & 15.92 & 44.12 & 0 & 12.32 & 0 & 1.31 & 32.61 & 29.94 & 5.94 \\
\hline Clostridium $O P A^{\star *}$ & 0 & 0 & 0 & 0 & 0 & 0 & 0 & 0 & 0 & 0 & 0 & 0 & 0 & 0 & 2.24 \\
\hline C.perfringens & 0.11 & 0.05 & 0.07 & 0 & 0.11 & 0.31 & 0.23 & 0.77 & 0.07 & 0.63 & 0.38 & 0.16 & 1.62 & 0.8 & 0.18 \\
\hline Eubacterium lentum & 3.37 & 3.32 & 6.78 & 1.42 & 0 & 0 & 0 & 10.38 & 0.24 & 3.88 & 3.03 & 0.54 & 6.43 & 9.62 & 0.93 \\
\hline Eubacterium sp. & 0.15 & 2.76 & 0.29 & 0.27 & 0 & 0 & 0.41 & 0.59 & 0.14 & 1.32 & 0.66 & 0.28 & 0.04 & 0.15 & 0.12 \\
\hline Peptostreptococcus sp. & 16.23 & 11.29 & 23.33 & 0 & 1.24 & 0 & 0 & 0 & 7.32 & 11.32 & 5.1 & 8.63 & 0 & 0 & 2.78 \\
\hline Ruminococcus sp. & 2.62 & 2.68 & 8.97 & 7.04 & 5.11 & 0 & 8.26 & 27.94 & 0 & 0 & 5.38 & 4.24 & 27.91 & 0 & 6.84 \\
\hline \multirow[t]{2}{*}{ Streptococcus mutans } & 0 & 0 & 0 & 0 & 0 & 0 & 0 & 0 & 0 & 0 & 0 & 0.13 & 0 & 1.5 & 0.2 \\
\hline & \multicolumn{15}{|c|}{ Bacteroidetes } \\
\hline Bacteroides hypermegas & 0.23 & 0.19 & 0.18 & 0 & 0.19 & 0.54 & 0.75 & 0 & 0.23 & 0 & 0 & 0.28 & 0 & 0.19 & 0 \\
\hline Bacteroides ruminicola & 0.33 & 0.42 & 0.91 & 0 & 0.66 & 1.95 & 2.94 & 4.46 & 0.83 & 4.21 & 1.54 & 1.29 & 0 & 1.34 & 0.69 \\
\hline Cytophaga sp. & 0.52 & 0.42 & 0.71 & 0.49 & 0.5 & 1.67 & 2.97 & 5.08 & 0.83 & 3.09 & 1.32 & 1.79 & 6.54 & 2.18 & 0.9 \\
\hline Hymenobacter, Pontibacter & 1.6 & 0 & 0.18 & 4.42 & 1.35 & 0 & 0.6 & 5.4 & 2.16 & 0 & 14.47 & 7.27 & 0.6 & 1.6 & 0 \\
\hline Hymenobacter/FRB & 0 & 0 & 0 & 0 & 0 & 15.57 & 24.92 & 3.61 & 0 & 0 & 0 & 3.45 & 12.43 & 0 & 0 \\
\hline Riemirella sp. & 0 & 0 & 0 & 0 & 0 & 7.59 & 5.57 & 0 & 0.97 & 0 & 0 & 1.78 & 10.22 & 4.98 & 1.82 \\
\hline \multirow[t]{2}{*}{ Sphingobacterium spiritovorum } & 0.55 & 0.16 & 1.03 & 0.37 & 0.32 & 1.24 & 2.27 & 1.53 & 0.21 & 1.89 & 0.23 & 0.69 & 3.45 & 1.03 & 0.79 \\
\hline & \multicolumn{15}{|c|}{ Deinococcus-Thermus } \\
\hline Deinococcus deserti & 11.35 & 5.87 & 11.21 & 0.19 & 2.67 & 35.23 & 15.12 & 0.42 & 0.05 & 0.17 & 0.08 & 0 & 1.64 & 46.31 & 14.37 \\
\hline Deinococcus radiophilus & 2.12 & 1.37 & 1.24 & 0 & 0 & 14.09 & 0 & 0 & 0 & 0 & 0 & 0 & 174.61 & 117.19 & 24.21 \\
\hline \multirow[t]{2}{*}{ Total } & 204.1 & 72.7 & 321.8 & 50.5 & 53.7 & 230.6 & 233.4 & 345.1 & 50.1 & 149.5 & 81.9 & 88.2 & 726.4 & 436 & 151 \\
\hline & \multicolumn{15}{|c|}{ Fungi } \\
\hline Fungi $18: 2, \mu \mathrm{g} / \mathrm{g}$ & 3.38 & 0 & 0 & 0 & 0 & 10.07 & 3.09 & 5.11 & 0 & 0 & 0 & 0 & 8.37 & 26.07 & 4.07 \\
\hline \multirow[t]{3}{*}{ Glomus etunicatum, cells $/ \mathrm{g} \times 10^{5}$} & 0 & 0 & 0 & 0 & 0 & 0 & 0 & 0 & 0 & 0 & 0 & 0.13 & 0 & 1.5 & 0.2 \\
\hline & \multicolumn{15}{|c|}{ Eucariotes } \\
\hline & 0 & 0 & 0 & 0.21 & 0 & 0.1 & 0.24 & 0.38 & 0 & 2.43 & 0.32 & 0.13 & 0 & 10.19 & 0.21 \\
\hline
\end{tabular}


Table 5. Composition of the community of microorganisms in the soil of Aral Sea-profiles 921-922 (samples 61 - 68).

\begin{tabular}{|c|c|c|c|c|c|c|c|c|}
\hline \multirow{3}{*}{$\begin{array}{l}\text { No. profile } \\
\text { Depth, cm }\end{array}$} & \multirow{2}{*}{\multicolumn{4}{|c|}{921}} & \multicolumn{4}{|c|}{922} \\
\hline & & & & & \multicolumn{4}{|c|}{ near saxaul } \\
\hline & $0-10$ & $10-30$ & $30-50$ & $50-65$ & $0-10$ & $10-30$ & $30-50$ & $50-65$ \\
\hline & \multicolumn{8}{|c|}{ Proteobacteria } \\
\hline Acetobacter-Rhodobacter group & 1.32 & 47.63 & 10.47 & 0 & 3.53 & 14.24 & 66.19 & 9.42 \\
\hline Aeromonas hydrophila & 1.58 & 70.53 & 17.57 & 0.41 & 5.74 & 10.86 & 43.11 & 4.95 \\
\hline Agrobacterium radiobacter & 0 & 0 & 0 & 0 & 0 & 0 & 0 & 0 \\
\hline Burkholderia cepacia & 0 & 0 & 0 & 0 & 0 & 1.83 & 1.56 & 1.15 \\
\hline Caulobactersp. & 0.19 & 0 & 0.91 & 0 & 0 & 3.75 & 17.49 & 1.04 \\
\hline Desulfovibrio sp. & 0 & 0 & 3.56 & 0 & 1.11 & 0.21 & 12.59 & 0 \\
\hline FeRed & 0 & 0 & 0 & 0 & 0 & 0.66 & 4.31 & 0.24 \\
\hline $\begin{array}{c}\text { Nitrobacter, Hyphomicrobium, } \\
\text { Xanthobacter+ }\end{array}$ & 0 & 0 & 4.63 & 2.32 & 0.16 & 9.55 & 0 & 5.45 \\
\hline Ochrobactrum sp. & 0 & 0 & 0 & 0 & 0 & 0.98 & 0 & 1.05 \\
\hline Pseudomonas fluorescens & 0.16 & 12.3 & 1.61 & 0 & 0.46 & 0.68 & 2.5 & 0.23 \\
\hline Pseudomonas putida & 0 & 0 & 10.49 & 0 & 0.97 & 3.04 & 8.21 & 0 \\
\hline Pseudomonas vesicularis & 0.48 & 15.14 & 8.7 & 0 & 1.13 & 2.56 & 9.41 & 1.6 \\
\hline Sphingomonas adgesiva & 0.3 & 23.37 & 2.4 & 0 & 0.76 & 2.65 & 13 & 1.53 \\
\hline Sphingomonas capsulata & 0.31 & 17.4 & 4.08 & 0 & 1.17 & 3.23 & 11.03 & 1.2 \\
\hline$W A R B^{\star}$ & 0.73 & 22.7 & 0 & 0 & 1.72 & 0 & 0 & 0.17 \\
\hline \multirow[t]{2}{*}{ Xanthomonas sp. } & 0.57 & 20.17 & 2.31 & 0 & 1.36 & 3.05 & 17.71 & 2.62 \\
\hline & \multicolumn{8}{|c|}{ Actinobacteria } \\
\hline Actinomadura roseola & 0 & 0 & 0.11 & 0 & 0 & 1.27 & 6.11 & 1.42 \\
\hline Actinomyces sp. & 0 & 0 & 11.97 & 6.67 & 0 & 14.47 & 22.69 & 27.5 \\
\hline Arthrobacter sp. & 0.48 & 3.02 & 6.16 & 2.01 & 0 & 7.04 & 6.09 & 2.67 \\
\hline Bifidobacterium sp. & 0 & 0 & 0 & 0 & 0 & 0 & 0.22 & 0.03 \\
\hline Cellulomonas sp. & 0.63 & 0 & 0 & 2.75 & 0 & 0 & 0 & 0 \\
\hline Corynebacterium sp. & 0.22 & 2.32 & 0 & 0.48 & 0 & 0 & 5.58 & 2.31 \\
\hline Mycobacterium sp. & 0 & 0 & 4.74 & 0 & 0 & 13.42 & 86.63 & 15.42 \\
\hline Nocardia sp. & 0 & 0 & 0 & 0 & 0 & 0 & 0 & 0 \\
\hline Nocardia carnea & 0 & 0 & 0 & 0 & 0 & 2.34 & 2.73 & 1.02 \\
\hline Nocardiopsis & 0.13 & 0 & 0.8 & 0 & 0 & 1.21 & 0 & 1.85 \\
\hline Propionibacterium freudenreichii & 0 & 0 & 3.74 & 0 & 0 & 8.84 & 43.48 & 15.47 \\
\hline Propionibacterium + & 0 & 0 & 0 & 1.08 & 0 & 0.3 & 0 & 0 \\
\hline
\end{tabular}




\section{Continued}

\begin{tabular}{|c|c|c|c|c|c|c|c|c|}
\hline Rhodococcus equi & 0.37 & 2.49 & 0.98 & 0 & 0.5 & 21.23 & 41.51 & 3.94 \\
\hline Rhodococcus terrae & 1.05 & 33.72 & 5.92 & 4.02 & 5.89 & 0 & 0 & 0 \\
\hline Streptomyces-Nocardiopsis & 0.16 & 1.91 & 0 & 1.21 & 0 & 12.69 & 35.9 & 7.63 \\
\hline & \multicolumn{8}{|c|}{ Firmicutes } \\
\hline Bacillus sp. & 0.8 & 2.38 & 3.03 & 0 & 2.35 & 3.38 & 8.91 & 2.33 \\
\hline Bacillus subtilis & 0 & 0 & 0.42 & 0 & 0 & 1.05 & 4.14 & 0.95 \\
\hline Butyrivibrio 1-2-13 & 0 & 0 & 0 & 0 & 0 & 0.98 & 3.88 & 0.84 \\
\hline Butyrivibrio 1-4-11 & 0 & 0 & 11.96 & 0 & 11.5 & 2.98 & 7.21 & 0.93 \\
\hline Butyrivibrio 7 S-14-3 & 0 & 0 & 2.12 & 0 & 0 & 1.58 & 9.79 & 0.54 \\
\hline Carboxydotermus & 0 & 0 & 0 & 0 & 0 & 1.77 & 21.5 & 17.22 \\
\hline Clostridium $O P A^{\star *}$ & 0 & 0 & 1.22 & 0 & 0 & 0 & 1.09 & 0 \\
\hline Clostridium perfringens & 0.07 & 0.8 & 0.22 & 0 & 0.09 & 0.25 & 0.55 & 0.18 \\
\hline Eubacterium sp. & 0.46 & 1.46 & 0.17 & 0 & 0.16 & 0.08 & 0.14 & 2.5 \\
\hline Eubacterium lentum & 0 & 1.74 & 0.25 & 0 & 0.57 & 2.63 & 4.71 & 1.06 \\
\hline Peptostreptococcus sp. & 8.25 & 19.02 & 20.28 & 14.83 & 8.82 & 15.62 & 8.93 & 7.89 \\
\hline Ruminococcus/Protozoa & 1.15 & 0 & 0 & 0 & 0 & 2.71 & 12.42 & 198.12 \\
\hline \multirow[t]{2}{*}{ Streptococcus mutans } & 0 & 0 & 0.16 & 0 & 0 & 0.57 & 0.34 & 0.46 \\
\hline & \multicolumn{8}{|c|}{ Bacteroidetes } \\
\hline Bacteroides hypermegas & 0 & 1.49 & 0.38 & 0 & 0 & 0.42 & 0.91 & 0 \\
\hline Bacteroides ruminicola & 0.2 & 9.32 & 1.71 & 0 & 0.73 & 2.07 & 8.03 & 0 \\
\hline Cytophaga sp. & 0.21 & 8 & 1.85 & 0 & 0.65 & 1.84 & 3.95 & 0.63 \\
\hline Hymenobacter, Pontibacter & 0.4 & 4.38 & 11.53 & 0 & 0.04 & 5.11 & 38.79 & 4.82 \\
\hline Hymenobacter/FRB & 0.37 & 0 & 4.44 & 0 & 0.65 & 19.09 & 40.67 & 0 \\
\hline Riemirella sp. & 0.49 & 0 & 5.98 & 0 & 0 & 0 & 20.55 & 0.87 \\
\hline \multirow[t]{2}{*}{ Sphingobacterium spiritovorum } & 0.05 & 2.45 & 3.08 & 0 & 0.16 & 2.6 & 10.69 & 1.37 \\
\hline & \multicolumn{8}{|c|}{ Deinococcus-Thermus } \\
\hline Deinococcus deserti & 1.18 & 0.17 & 3.18 & 2.59 & 1.6 & 11.83 & 17.76 & 4.78 \\
\hline Deinococcus radiophilus & 0 & 0 & 1.18 & 0 & 0 & 7.22 & 0 & 0.3 \\
\hline Total & 22.31 & 323.91 & 174.31 & 38.37 & 51.82 & 223.88 & 683.01 & 355.7 \\
\hline \multicolumn{9}{|l|}{ Fungi } \\
\hline Fungi $18: 2, \mu \mathrm{g} / \mathrm{g}$ & 0 & 0 & 2.66 & 0 & 0.63 & 0.72 & 5.48 & 27.83 \\
\hline \multirow[t]{3}{*}{ Glomus etunicatum, cells/g } & 0 & 0 & 0 & 0 & 0 & 0 & 0 & 0 \\
\hline & \multicolumn{8}{|c|}{ Eucariotes } \\
\hline & 0.09 & 0 & 0.87 & 0 & 0.24 & 0 & 0 & 1.56 \\
\hline
\end{tabular}


Arbuscular mycorhiza fungi, Glomus etunicatum, were found in some samples taken in the soil under saxaul (Table 1), on bare land (Table 3) and on the mainland (Table 4). This indicates to extended area of nutrient consumption by saxaul through micorhiza micromyceters and the contribution of these fungi to different stages of the soil formation process on the dried seabed. Some of soil samples showed markers of cyanobacteria (Table 3 ).

\section{Findings}

1) Bacteria of the community of microorganisms in different parts of the soil cover on the dried seabed of the Aral Sea and on the mainland belong to five bacterial phyla: Proteobacteria Actinobacteria Firmicutes Bacteroidetes and Deinococcus-Thermus. In general, 59 bacterial species of 43 genera were reconstructed. The total population varied from $10^{5}$ cells/g to $10^{8}$ cells/g of the soil. The mainland is richer in terms of microorganisms at all studied depths. However, there were also profiles under saxaul and bare land areas, where the total population of microorganisms was comparable with that on the mainland. The content of micromycetes is higher in the soil under saxaul. Thus, the total population of microorganisms was not indicative for the soil on the dried seabed of the Aral Sea in different environmental contexts.

2) The association Aeromonas hydrophila-Arthrobacter sp. plays the key role at the first stages of the soil formation process on the dried seabed of the Aral Sea. This association is followed by salt-resistant Agrobacterium sp. and humus-accumulating Propionibacterium freudenreichii, activity of which is also very important for the formation of the soil cover.

3) Two types of bacteria were found in the community of microorganisms in the studied profiles. Those are the Deinococcus (D. deserti, D. radiophilus) type bacteria that are highly resistant to radiation and that were described under conditions of the Sahara Desert and the Hymenobacter and Pontibacter type bacteria that were identified in Chinese deserts. In terms of microbiology, this testifies that the studied soil belongs to desert type.

4) The research showed that unique processes that are of great scientific interest take place on the dried bed of the Aral Sea. These processes develop long before their visual display. The need to study these processes is evident. Regular monitoring of the environmental situation in Prearalie is important since this area is a risk zone for health of the people. At the same time, studying such properties of the dried seabed cover as salt composition and microbiological composition allowed tracing formation of initial soil on sea sediments followed by desert-type soil formation. The research of soil cover development will help to understand the kernel of desertification process as a whole from a microbiological standpoint.

\section{Conflicts of Interest}

The authors declare no conflicts of interest regarding the publication of this paper. 


\section{References}

Benz, M., Schink, B., \& Brune, A. (1998). Humic Acid Reduction by Propionibacterium freudenreichii and Other Fermentating Bacteria. Applied and Environmental Microbiology, 64, 4507-4212.

Dukhovny, V. A., Navratil, P., Ruziev, I., Stulina, G., \& Roschenko, Y. (2008). Comprehensive Remote Sensing and Ground-Based Studies of the Dried Aral Sea Bed. Tashkent: SIC ICWC.

Groot, A., Chapon, V., Servant, P., \& Christ, R. (2005). Deinococcus deserti SP. Nov., a Gamma-Radiationtolerant Bacterium Isolated from the Sahara Desert. International Journal of Systematic and Evolutionary Microbiology, 55, 2441-2446. https://doi.org/10.1099/ijs.0.63717-0

Katsnelson, H., \& Sirois, J. C. (1961). Auxin Production by Species of Arthrobacter. Nature, 191, 1323-1324. https://doi.org/10.1038/1911323a0

Katsnelson, H., Sirois, J. C., \& Shirley, E. C. (1962). Production of a Gibberellin-Like Substance by Arthrobacter globiformis. Nature, 196, 1012-1013. https://doi.org/10.1038/1961012b0

Kerr, J. R. (1999). Bacterial Inhibition of Fungal Growth and Pathogenicity. Microbial Ecology in Health and Disease, 11, 129-142. https://doi.org/10.1080/089106099435709

Lengeler, Y., Drevs, G., \& Shlegel, G. (2005). Modern Microbiology. Prokaryotes (654 p). Moscow: Mir Publishers.

Marialigeti, K. (1979). On the Community-Structure of the Gut-Microbiota of Eisenia lucens (Annelida, Oligochaeta). Pedobiologia, 19, 231-220.

Osipov G. A. (1997). A Method for Determining Generic Composition of the Community of Microorganisms. Patent of Invention No. 2086642 of 10.08.97, 12. (in Russia)

Osipov, G. A., \& Turova, E. S. (1997). Studying Species Composition of Microbial Communities with the Use of Gas Chromatography-Mass Spectrometry: Microbial Community of Kaolin. FEMS Microbiology Reviews, 20, 437-446.

https://doi.org/10.1111/j.1574-6976.1997.tb00328.x

Rabotnov, T. A. (1992). Phytocenology (3rd ed., 176 p.). Moscow: Izdatelstvo MGU.

Stulina, G. V., \& Sektimenko, V. (2004). The Change in Soil Cover on the Exposed Bed of Aral Sea. Journal of Marine Systems, 47, 121-125.

https://doi.org/10.1016/j.jmarsys.2003.12.014

Verhovtseva, N. V., \& Osipov, G. A. (2008). Gas Chromatography Mass-Spectrometry Method in the Studies of Microbial Communities of the Agro-Ecosystem Soil. Problem of Agrochemistry and Ecology, 1, 51-54.

Zhang, L., Dai, J., Tang, Y., Luo, X., Wang, Y., An, H., Fang, C., \& Zhang, C. (2009). Hymenobacter Deserti SP. Nov., Isolated from the Desert of Xinjiang, China. International Journal of Systematic and Evolutionary Microbiology, 59, 77-82. https://doi.org/10.1099/ijs.0.000265-0

Zhou, Y., Wang, X., Liu, H., Zhang, K. Y., Zhang, Y. Q., Lai, R., \& Li, W. J. (2007). Pontibacter Akesuensis SP. Nov., Isolated from a Desert Soil in China. International Journal of Systematic and Evolutionary Microbiology, 57, 321-325.

Zvyagintsev, D. G. (1991). Methods of Soil Microbiology and Biochemistry (303 p.). Moscow: MSU. 